\title{
Mechanisms of root response to manganese stress in wheat seedlings and significance of selenium supplementation - bio- chemical and cytological studies
}

\author{
Apolonia Sieprawska 1,**, Magdalena Skórka ${ }^{1}$, Elżbieta Bednarska-Kozakiewicz ${ }^{2}$, Katarzyna Niedojadło ${ }^{2}$, \\ Agnieszka Janiak ${ }^{3}$, Anna Telk ${ }^{4}$ and Maria Filek ${ }^{1}$ \\ 1 Department of Biochemistry, Biophysics and Biotechnology, Institute of Biology, Pedagogical University, \\ Podchorążych 2, 30-084 Krakow, Poland; magdalena.skorka1@student.up.krakow.pl; maria.filek@up.kra- \\ kow.pl \\ 2 Faculty of Biological and Veterinary Sciences, Institute of Biology, Nicolaus Copernicus University in \\ Toruń, Lwowska 1, 87-100 Toruń, Poland; ebedn@umk.pl; karask@umk.pl \\ 3 Institute of Biology, Biotechnology and Environmental Protection, Faculty of Natural Sciences, University of \\ Silesia in Katowice, Jagiellońska 28, 40-032 Katowice, Poland; agnieszka.janiak@us.edu.pl \\ 4 Department of Analytical Chemistry, Faculty of Chemistry, Jagiellonian University, Gronostajowa 2; 30 - \\ 387 Krakow, Poland; anna.telk@uj.edu.pl \\ * Correspondence: apolonia.sieprawska@up.krakow.pl
}

\begin{abstract}
In recent years cultivated soils have been increasingly supplemented with nutrients that at low doses are necessary for proper plant functioning but become toxic at high doses. New methods are needed to prevent these destructive actions, and for this reason we studied the effects of two elements - Mn treated as a stressor and Se treated as a potential defense in two wheat cultivars. The intensity of stress was manifested in tissue browning and weight reduction and was determined by an increase in lipid peroxidation and quantitative analysis of hydrogen peroxide levels. It was found that the excess of $\mathrm{Mn}$ in the substrate caused more intense changes in these indicators in the root system than in the leaves, and that Se presence partly eliminated the stress evoked effects. Moreover, Mn-treatment was accompanied by a greater absorption of this element by the roots, and a reduced uptake of other elements $(\mathrm{K}, \mathrm{Fe}, \mathrm{S}, \mathrm{P})$, with the exception of $\mathrm{Ca}$, an increase in which was observed especially in the additional presence of Se. It was suggested that the rise in Ca level can lead to modification of cell differentiations and may be one of the steps in defense mechanisms. The change in the direction of cell differentiation in the apical part of the root was observed microscopically under Mn stress and was accompanied by a quantitative increase in 5-met C. Based on DNA methylation profiles detected by MSAP we concluded that various types of methylation sites may be activated under Mn treatment in roots.
\end{abstract}

Keywords: manganese stress, selenium, wheat seedlings

\section{Introduction}

Understanding the mechanism of action of biotic and abiotic stresses in plants still requires extensive research in order to unveil biochemical properties of cells that lead to minimization of toxic effects. The intensity of a stressor action, as well as specific response of species and even cultivars to the stress, are some of the reasons that make a detailed description of stages in stress adaptation process difficult. In most research papers overproduction of reactive oxygen species (ROS), is accepted as an important step in the mechanism the stress action [1]. One of those ROS are the superoxide anion radical and $\mathrm{H} 2 \mathrm{O} 2$ responsible, among others, for inducing changes in the structure of cell membranes by increasing saturation of the fatty acids (recorded as an increase in MDA content) [2]. Thus, MDA level fluctuation is demonstrated as one of the factors 
informing about the stress intensity. The modification of the lipid structure may disturb the activity of protein channels and transporters located in the membranes and affect ion transportation. Among the ions especially important for proper functioning of cells are the cations of calcium (Ca), magnesium $(\mathrm{Mg})$, and potassium $(\mathrm{K})$, and the anions of sulfur (S) and phosphorus (P) (analyzed in mg concentrations), and also the cations of manganese $(\mathrm{Mn})$, zinc $(\mathrm{Zn})$, copper $(\mathrm{Cu})$, and iron $(\mathrm{Fe})$ (present in $\mu \mathrm{g}$ amounts). The role of $\mathrm{Ca}$ in plant cell homeostasis is particularly significant, as it mediates signals from the roots to the shoots in the process of adaptation to the environmental conditions and ROS overproduction [3]. Magnesium presence in activity centers of organic components is essential to stimulate many metabolic reactions that depend on protein synthesis, phosphorylation, photooxidation or enzyme activation [4]. Similarly, K is involved in protein synthesis, enzyme activation and energy transfer, but also in osmoregulation and cationanion balance, which were analyzed in aspects of biotic and abiotic stresses [5]. Sulfur presence in amino acids of numerous enzymes increases plant tolerance to stress factors [6]. The importance of $\mathrm{P}$ is mainly considered in terms of its contribution to the structure of nucleic acids. This macronutrient stabilizes the membrane structures and mediates the activation of enzymes and carbohydrate metabolism [7, 8]. Membrane proteins containing $S$ and/or $P$ may serve as transporters in the translocation of various ions from and to cells [9]. Zinc, copper and iron serve as co-factors of many enzymes, including those participating in antioxidant protection [10]. Zinc participates in the regulation of gene expression shaping plant tolerance under stress and is involved in protein synthesis and carbohydrate metabolism [11]. Iron is a fundamental element of biomolecules controlling the structure and function of chloroplasts and synthesis of chlorophyll [12]. Uptake of Fe into cells may be supported by $\mathrm{Cu}$ ions [13].

In recent years manganese, due to its increasing levels in the soil, has received special attention. The ion is a cofactor and activator of numerous plant enzymes, such as oxalate oxidase, oxalate decarboxylase, enzymes involved in fatty acid synthesis, or synthesis of deoxyribonucleic acid and ribonucleic acid [14, 15]. Manganese presence is indispensable to maintain the redox balance and electron transfer reactions, which is why it plays a valid role in the regulation of excess ROS generation under stress [16]. It is suggested that exogenous application of Mn ions limited damage to plant cells by improving antioxidant defense systems, ion homeostasis and diminishing toxic changes in lipid peroxidation, particularly under metal stress conditions [17, 18, 19]. However, too high concentration of $\mathrm{Mn}$, above the optimal content in cells (specific for plant cultivars), may induce destructive effects in plant tissues by initiating stress reactions. Similarly, as under other stresses, ROS generation and activation of oxidation processes were demonstrated under Mn excess in plant cells [14, 20-22]. It was suggested that Mn toxicity is related to oxidation of $\mathrm{Mn}$ in the apoplast and that Mn may serve as an oxidizer of lipids and proteins [23]. The ability of Mn to bind with sulfhydryl groups of proteins disturbs their chemical structure and in consequence disrupts the movement of basic components in plant cells [24]. A decrease in the absorption of elements such as Fe, $\mathrm{Mg}, \mathrm{Ca}$ and $\mathrm{P}$, characterized by a similar size of ions or the strength of ligand binding, was shown by Shi and Zhu [25] and Millaleo et al. [26]. Chen et al. [27] suggested that the modification of protein structure in the root system was the primary reason leading to growth inhibition in these organs. This suggests that the anatomical and chemical structure of the root system is essential to ensure proper uptake of substances from the soil and their transport to the leaves. Mn can be transferred via the plasma membranes of the root cells in a symplastic transport, or via the space between the root cells (apoplastic transport). Following absorption in the roots, Mn can be accumulated in the vacuole (as its main storage place) and/or the cell wall, and may also be transported to the leaves (via xylem). Rajpoot et al. [28] showed that excessive Mn content (1-2 mM) in the growth media drastically changed the physicochemical conditions in the apical part of the roots. 
One of the methods of protecting plants against stress induced by an excess of metals in the soil is the application of micro-amounts of selenium (Se) ions [29, 30]. Such studies in the aspect of stress caused by Mn have not been conducted so far. Selenium is not required for plant physiological processes, but its presence is valued, especially in plants used as food products for humans and animals [31]. It is suggested that the mechanism of Se-based protection involves its blocking the uptake and transport of toxic substances [32] and/or reducing the overproduction of ROS [29, 33]. Another mechanism may be a Se-mediated modification of the methylation pattern disturbed by stress factors $[34,35]$.

DNA methylation regulates many biological processes in plants, including their growth and development [36-38]. Changes in DNA methylation were also documented in plants exposed to biotic and abiotic stresses, however, its direction (demethylation and de-novo methylation) depended on factors such as plant species, developmental stage and stress intensity [39, 40]. DNA methylation may enhance crop adaptation to stress by serving as a protective system that maintains genome integrity, and as the main epigenetic mechanism that controls gene expression in cells [41, 42]. Moreover, it was shown that stress resistant genotypes responded to stress with a decrease in the percentage of 5-methylcytosine (5-metC), in the DNA pattern, while sensitive ones with an increase in methylation level [43]. However, other studies demonstrated the same pattern of changes in cytosine methylation irrespective of plant stress sensitivity [39]. Therefore, further research in this area should be carried out to learn more about the mechanism of action of both stress and adaptation processes.

The presented study aims to demonstrate a possible protective effect of Se ions in wheat subjected to toxic concentration of $\mathrm{Mn}$ and to estimate the influence of $\mathrm{Mn}$ and Se treatment on DNA methylation. Two cultivars of wheat, differing in visible symptoms of response to $\mathrm{Mn}$, were selected for analysis. The aim of the research was achieved by: i) determining the amount of hydrogen peroxide and the degree of lipid peroxidation as indicators of stress intensity; ii) assessing changes in the content of macro- and microelements, including Mn and Se, and modification of the membrane permeability as effect $\mathrm{Mn}$ and Se mediation in the transport of nutrients from the roots to the leaves; iii) measuring the content of soluble sugars and starch, important metabolites that may indicate disturbances in metabolic processes; iv) visualizing 5-metC content in the leaf and root cells; v) estimating the proportion of demethylated and methylated cytosine residues within CCGG sequence in DNA from the whole leaves and roots using MethylationSensitive Amplified Polymorphism (MSAP) method. Special attention was paid to the reactions occurring in the root system, the place of direct contact of $\mathrm{Mn} / \mathrm{Mn}+$ Se with the plant tissues.

\section{Results}




\subsection{Biochemical analysis}

No significant visual differences between the tested cultivars were found in the seedlings grown under the control conditions. This was also demonstrated in the similarities of the fresh weight of their leaves and roots. Only a slightly higher weight (statistically insignificant) was recorded in cv. Nimfa's leaves as compared with cv. Alibi (Table 1). Growth in the presence of Mn decreased the weight of both leaves and roots by about three times (leaves) or about seven times (roots), independently of the cultivar. Moreover, both cultivars showed signs of leaf edge yellowing. Damage was also visible in the root system, mainly in cv. Alibi. In this cultivar, shortening and deformation of the root system and its stronger browning were more significant than in cv. Nimfa. In Mn+Se media, a weight increase of the examined organs was noted as compared with Mn only treatment. For plants grown on the media containing only Se, fresh weight of both leaves and roots was comparable to that of the control.

The control seedlings accumulated a greater amount of $\mathrm{Mn}$ in the roots than in the leaves (Table 1). The cultivation on Mn-containing media resulted in a significant increase in the content of this element in both organs, especially in the root systems of the investigated cultivars. The changes were more pronounced in cv. Nimfa than in cv. Alibi. Following joint application of $\mathrm{Mn}$ and Se, Mn level slightly increased in the leaves and decreased in the roots of $\mathrm{cv}$. Nimfa, while in cv. Alibi the opposite effect was observed (as compared with Mn treatment). The presence of Se alone did not affect the content of Mn in the leaves of any cultivar, but decreased Mn concentration in the root systems.

An analysis of Se content in the tested objects showed only trace amounts of this element in the control and Mn variants. In the roots, Se administration, both alone and with $\mathrm{Mn}$, increased Se content by about six to nine times for cv. Nimfa and cv. Alibi, respectively. In the leaves, the presence of Mn more than doubled decreased the Se uptake, as compared with Se added individually, especially in cv. Alibi.

The studied cultivars differed in their content of macro- and micronutrients (Table 1). In the control leaves of $\mathrm{cv}$. Nimfa, higher concentrations of $\mathrm{Ca}, \mathrm{Mg}, \mathrm{Zn}$ and Fe were recorded than in cv. Alibi, while the root system of cv. Nimfa was richer in $\mathrm{Mg}, \mathrm{S}, \mathrm{Cu}$ and Fe than that of $\mathrm{cv}$. Alibi. Mn presence restricted the accumulation of all tested elements in the leaves of both cultivars. In the root system, an increase in the content of $\mathrm{P}, \mathrm{S}$ and $\mathrm{Zn}$ (both cultivars) and Ca (cv. Nimfa) was recorded. Simultaneous treatment with Mn and Se reduced the content of $\mathrm{P}, \mathrm{Cu}$ and $\mathrm{Fe}$ in the leaves of the tested objects and additionally of $\mathrm{K}$ in cv. Nimfa, in comparison with the plants exposed to Mn alone. Moreover, in the leaves of cv. Alibi a drop in the content of $\mathrm{Ca}, \mathrm{Mg}$ and $\mathrm{S}$, was noticed. In the root system, there was an increase in the level of $\mathrm{P}$ and Fe for both cultivars, while the concentration of the other elements decreased in cv. Nimfa and rose in cv. Alibi (as compared with Mn alone). In the presence of Se alone, the content of all elements in both leaves and roots was close to that recorded for the controls.

An analysis of $\mathrm{H}_{2} \mathrm{O}_{2}$ level indicated its much more abundant presence in the leaves than in the roots of all studied plants (Figure 1A). In control plants, no significant differences in the content of this compound between the tested plants were found. After treatment with Mn both cultivars showed increased concentration of $\mathrm{H}_{2} \mathrm{O}_{2}$ in the leaves, and in cv. Alibi it rose by about 1.5 times. In the roots of both cultivars the content of $\mathrm{H}_{2} \mathrm{O}_{2}$ grew by about three to five times (more in cv. Nimfa). When $\mathrm{Mn}$ and Se were administered simultaneously, the concentration of $\mathrm{H}_{2} \mathrm{O}_{2}$ in the leaves of both cultivars decreased in relation to that observed for Mn (especially in cv. Alibi). In the roots, hydrogen peroxide level changed only to a small extent as compared with Mn-only treatment. The presence of Se added individually did not significantly affect the level of $\mathrm{H}_{2} \mathrm{O}_{2}$ of the studied objects and its concentration in both leaves and roots was close to that in the control. 
Table 1. Fresh weight $[\mathrm{g}]$ and concentration of elements: $\mathrm{Ca}, \mathrm{Mg}, \mathrm{K}, \mathrm{P}, \mathrm{S}$ and $\mathrm{Mn}\left[\mathrm{mg} \cdot \mathrm{g}^{-1} \mathrm{DW}\right] \mathrm{and} \mathrm{Cu}, \mathrm{Zn}$ Fe and Se $\left[\mu \mathrm{g} \cdot \mathrm{g}^{-1} \mathrm{DW}\right]$ in the leaves and roots of cvs. Alibi and Nimfa in control plants and after treatment with $10 \mathrm{mM} \mathrm{MnCl}_{2}, 10 \mathrm{mM} \mathrm{MnCl}_{2}+15 \mu \mathrm{M} \mathrm{SeCl}_{2}$ and $15 \mu \mathrm{M} \mathrm{SeCl}$

\begin{tabular}{|c|c|c|c|c|c|c|c|c|c|c|c|c|}
\hline & & $\begin{array}{c}\text { Fresh } \\
\text { weight }[\mathrm{g}]\end{array}$ & $\begin{array}{c}\text { Mn } \\
{\left[\mathrm{mg} \cdot \mathrm{g}^{-1} \mathrm{DW}\right]}\end{array}$ & $\begin{array}{c}\mathbf{S e} \\
{\left[\mu \mathrm{g} \cdot \mathrm{g}^{-1} \mathrm{DW}\right]}\end{array}$ & $\begin{array}{c}\mathbf{C a} \\
{\left[\mathrm{mg} \cdot \mathrm{g}^{-1} \mathrm{DW}\right]}\end{array}$ & $\begin{array}{c}\text { Mg } \\
{\left[\mathrm{mg} \cdot \mathrm{g}^{-1} \mathrm{DW}\right]}\end{array}$ & $\begin{array}{c}\mathbf{K} \\
{\left[\mathrm{mg} \cdot \mathrm{g}^{-1} \mathrm{DW}\right]}\end{array}$ & $\begin{array}{c}\mathbf{P} \\
{\left[\mathrm{mg} \cdot \mathrm{g}^{-1} \mathrm{DW}\right]}\end{array}$ & $\begin{array}{c}\mathbf{S} \\
{\left[\mathrm{mg} \cdot \mathrm{g}^{-1} \mathrm{DW}\right]}\end{array}$ & $\begin{array}{c}\mathbf{C u} \\
{\left[\mu \mathrm{g} \cdot \mathrm{g}^{-1} \mathrm{DW}\right]}\end{array}$ & $\begin{array}{c}\mathbf{Z n} \\
{\left[\mu \mathrm{g} \cdot \mathrm{g}^{-1} \mathrm{DW}\right]}\end{array}$ & $\begin{array}{c}\mathbf{F e} \\
{\left[\mu \mathrm{g} \cdot \mathrm{g}^{-1} \mathrm{DW}\right]}\end{array}$ \\
\hline \multicolumn{13}{|c|}{ Leaves } \\
\hline \multirow{4}{*}{ 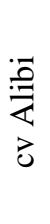 } & control & $0.423 \pm 0.011^{\mathrm{a}}$ & $0.21 \pm 0.03^{c}$ & $0.01 \pm 0.01^{\mathrm{c}}$ & $5.88 \pm 0.05^{\mathrm{a}}$ & $3.60 \pm 0.06^{\mathrm{a}}$ & $89.81 \pm 0.25^{\mathrm{b}}$ & $14.80 \pm 0.08^{\mathrm{a}}$ & $7.32 \pm 0.03^{b}$ & $15.94 \pm 0.03^{\mathrm{a}}$ & $95.94 \pm 0.12^{\mathrm{a}}$ & $212.08 \pm 3.12^{b}$ \\
\hline & $\mathrm{Mn}$ & $0.131 \pm 0.008^{c}$ & $6.63 \pm 0.02^{\mathrm{a}}$ & $0.01 \pm 0.01^{\mathrm{c}}$ & $1.41 \pm 0.01^{\mathrm{c}}$ & $1.35 \pm 0.01^{\mathrm{b}}$ & $53.23 \pm 0.74^{\mathrm{d}}$ & $8.45 \pm 0.05^{\mathrm{b}}$ & $4.24 \pm 0.04^{\mathrm{c}}$ & $3.96 \pm 0.03^{\mathrm{c}}$ & $16.68 \pm 0.03^{c}$ & $90.76 \pm 2.07^{c}$ \\
\hline & $\mathrm{Mn}+\mathrm{Se}$ & $0.165 \pm 0.009^{b}$ & $5.32 \pm 0.02^{b}$ & $0.08 \pm 0.01^{b}$ & $1.00 \pm 0.03^{\mathrm{d}}$ & $1.19 \pm 0.0$ & $57.27 \pm 0.35^{\mathrm{c}}$ & $7.34 \pm 0.09^{c}$ & $4.07 \pm 0.04^{\mathrm{d}}$ & $2.86 \pm 0.02^{\mathrm{d}}$ & $17.84 \pm 0.07^{\mathrm{b}}$ & $78.60 \pm 1.58^{d}$ \\
\hline & $\mathrm{Se}$ & $0.430 \pm 0.012^{\mathrm{a}}$ & $0.21 \pm 0.01^{\mathrm{c}}$ & $0.21 \pm 0.01^{\mathrm{a}}$ & $4.85 \pm 0.08^{b}$ & $3.62 \pm 0.03^{\mathrm{a}}$ & $95.50 \pm 0.26^{\mathrm{a}}$ & $14.91 \pm 0.05^{\mathrm{a}}$ & $12.25 \pm 0.12^{\mathrm{a}}$ & $14.27 \pm 0.05^{\mathrm{b}}$ & $95.66 \pm 0.37^{a}$ & $278.90 \pm 4.06^{\mathrm{a}}$ \\
\hline \multirow{4}{*}{$\begin{array}{l}\stackrel{\pi}{\rightleftarrows} \\
\text { 艺 } \\
\text { 己 }\end{array}$} & control & $0.466 \pm 0.013^{\mathrm{a}}$ & $0.17 \pm 0.01^{\mathrm{c}}$ & $0.00 \pm 0.01^{\mathrm{c}}$ & $6.49 \pm 0.05^{\mathrm{a}}$ & $4.05 \pm 0.03^{\mathrm{a}}$ & $89.68 \pm 0.75^{b}$ & $12.97 \pm 0.07^{\mathrm{a}}$ & $5.88 \pm 0.03^{b}$ & $10.68 \pm 0.02^{\mathrm{a}}$ & $99.64 \pm 0.27^{\mathrm{a}}$ & $230.08 \pm 3.23^{\mathrm{a}}$ \\
\hline & $\mathrm{Mn}$ & $0.137 \pm 0.006^{c}$ & $9.81 \pm 0.03^{b}$ & $0.00 \pm 0.01^{\mathrm{c}}$ & $1.71 \pm 0.02^{\mathrm{d}}$ & $1.50 \pm 0.01^{\mathrm{d}}$ & $59.18 \pm 1.66^{\mathrm{c}}$ & $8.57 \pm 0.10^{\mathrm{c}}$ & $3.86 \pm 0.02^{\mathrm{d}}$ & $5.49 \pm 0.02^{c}$ & $24.33 \pm 0.05^{\mathrm{d}}$ & $80.16 \pm 1.35^{\mathrm{c}}$ \\
\hline & $\mathrm{Mn}+\mathrm{Se}$ & $0.176 \pm 0.004^{b}$ & $12.26 \pm 0.04^{\mathrm{a}}$ & $0.08 \pm 0.01^{\mathrm{b}}$ & $2.18 \pm 0.06^{\mathrm{c}}$ & $1.79 \pm 0.03^{c}$ & $48.96 \pm 0.49^{\mathrm{d}}$ & $7.46 \pm 0.03^{\mathrm{d}}$ & $4.25 \pm 0.05^{\mathrm{c}}$ & $3.62 \pm 0.02^{\mathrm{d}}$ & $26.68 \pm 0.04^{\mathrm{c}}$ & $70.96 \pm 1.28^{\mathrm{d}}$ \\
\hline & $\mathrm{Se}$ & $0.465 \pm 0.015^{\mathrm{a}}$ & $0.15 \pm 0.01^{\mathrm{c}}$ & $0.18 \pm 0.01^{\mathrm{a}}$ & $4.94 \pm 0.05^{\mathrm{b}}$ & $3.22 \pm 0.08^{\mathrm{b}}$ & $91.99 \pm 1.17^{\mathrm{a}}$ & $10.90 \pm 0.04^{\mathrm{b}}$ & $9.23 \pm 0.06^{\mathrm{a}}$ & $10.56 \pm 0.01^{\mathrm{b}}$ & $58.80 \pm 0.21^{\mathrm{b}}$ & $197.53 \pm 2.84^{\mathrm{b}}$ \\
\hline \multicolumn{13}{|c|}{ Roots } \\
\hline \multirow{4}{*}{ 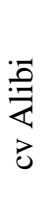 } & control & $0.247 \pm 0.011^{\mathrm{a}}$ & $0.37 \pm 0.01^{\mathrm{c}}$ & $0.00 \pm 0.01^{b}$ & $1.85 \pm 0.02^{b}$ & $1.51 \pm 0.02^{\mathrm{a}}$ & $67.84 \pm 0.07^{b}$ & $7.65 \pm 0.01^{\mathrm{d}}$ & $3.87 \pm 0.01^{\mathrm{c}}$ & $51.74 \pm 0.25^{b}$ & $71.31 \pm 0.13^{\mathrm{d}}$ & $1316.38 \pm 21.17^{\mathrm{a}}$ \\
\hline & $\mathrm{Mn}$ & $0.035 \pm 0.003^{\mathrm{d}}$ & $13.76 \pm 0.02^{b}$ & $0.00 \pm 0.01^{\mathrm{b}}$ & $1.49 \pm 0.03^{c}$ & $1.11 \pm 0.01^{\mathrm{c}}$ & $40.82 \pm 0.11^{\mathrm{c}}$ & $9.54 \pm 0.10^{\mathrm{b}}$ & $5.33 \pm 0.03^{b}$ & $27.09 \pm 0.99^{\mathrm{d}}$ & $83.36 \pm 0.24^{b}$ & $1041.06 \pm 19.55^{\mathrm{d}}$ \\
\hline & $\mathrm{Mn}+\mathrm{Se}$ & $0.056 \pm 0.004^{\mathrm{c}}$ & $18.16 \pm 0.03^{\mathrm{a}}$ & $0.09 \pm 0.01^{\mathrm{a}}$ & $3.03 \pm 0.08^{\mathrm{a}}$ & $1.26 \pm 0.02^{\mathrm{b}}$ & $41.04 \pm 0.12^{\mathrm{c}}$ & $9.80 \pm 0.08^{\mathrm{a}}$ & $5.98 \pm 0.09^{\mathrm{a}}$ & $32.03 \pm 0.30^{c}$ & $86.58 \pm 0.47^{a}$ & $1210.26 \pm 19.42^{b}$ \\
\hline & $\mathrm{Se}$ & $0.203 \pm 0.007^{b}$ & $0.27 \pm 0.01^{\mathrm{d}}$ & $0.08 \pm 0.01^{\mathrm{a}}$ & $1.87 \pm 0.03^{b}$ & $1.50 \pm 0.02^{\mathrm{a}}$ & $77.35 \pm 0.79^{\mathrm{a}}$ & $7.87 \pm 0.03^{c}$ & $3.89 \pm 0.02^{\mathrm{c}}$ & $74.29 \pm 0.31^{\mathrm{a}}$ & $82.51 \pm 0.20^{c}$ & $1140.36 \pm 17.46^{\mathrm{c}}$ \\
\hline \multirow{4}{*}{$\begin{array}{l}\underset{\pi}{\Xi} \\
\text { Z } \\
\text { 己 }\end{array}$} & control & $0.238 \pm 0.006^{\mathrm{a}}$ & $0.35 \pm 0.01^{\mathrm{c}}$ & $0.00 \pm 0.01^{b}$ & $1.28 \pm 0.02^{\mathrm{d}}$ & $1.65 \pm 0.01^{\mathrm{b}}$ & $69.85 \pm 0.97^{\mathrm{a}}$ & $7.48 \pm 0.01^{\mathrm{c}}$ & $4.17 \pm 0.02^{c}$ & $66.14 \pm 0.35^{\mathrm{a}}$ & $70.00 \pm 0.18^{c}$ & $1546.79 \pm 22.13^{b}$ \\
\hline & $\mathrm{Mn}$ & $0.041 \pm 0.002^{\mathrm{d}}$ & $16.03 \pm 0.03^{\mathrm{a}}$ & $0.00 \pm 0.01^{\mathrm{b}}$ & $2.76 \pm 0.02^{\mathrm{a}}$ & $1.30 \pm 0.03^{c}$ & $34.97 \pm 0.19^{c}$ & $8.04 \pm 0.03^{b}$ & $5.08 \pm 0.01^{\mathrm{a}}$ & $20.67 \pm 0.08^{c}$ & $98.61 \pm 0.27^{\mathrm{a}}$ & $903.09 \pm 9.26^{\mathrm{d}}$ \\
\hline & $\mathrm{Mn}+\mathrm{Se}$ & $0.057 \pm 0.003^{c}$ & $15.31 \pm 0.02^{\mathrm{b}}$ & $0.06 \pm 0.01^{\mathrm{a}}$ & $2.01 \pm 0.01^{\mathrm{b}}$ & $1.24 \pm 0.02^{\mathrm{d}}$ & $34.65 \pm 0.90^{c}$ & $8.38 \pm 0.03^{\mathrm{a}}$ & $5.02 \pm 0.01^{\mathrm{b}}$ & $18.29 \pm 0.19^{\mathrm{d}}$ & $69.53 \pm 0.36^{\mathrm{d}}$ & $1003.73 \pm 11.17^{\mathrm{c}}$ \\
\hline & $\mathrm{Se}$ & $0.210 \pm 0.005^{\mathrm{b}}$ & $0.24 \pm 0.01^{\mathrm{d}}$ & $0.06 \pm 0.01^{\mathrm{a}}$ & $1.73 \pm 0.01^{\mathrm{c}}$ & $1.71 \pm 0.01^{\mathrm{a}}$ & $64.81 \pm 1.83^{\mathrm{b}}$ & $7.10 \pm 0.02^{\mathrm{d}}$ & $3.17 \pm 0.02^{\mathrm{d}}$ & $51.14 \pm 0.46^{\mathrm{b}}$ & $75.95 \pm 0.42^{b}$ & $2403.00 \pm 23.32^{\mathrm{a}}$ \\
\hline
\end{tabular}

Data are averages from three independent biological replications \pm SE. The same letters indicate not significant differences between treatments registered separately for each wheat genotype $(p \leq 0.5)$ 
Lipid peroxidation by ROS, recorded as a change in MDA concentration, was slightly higher in cv. Alibi and in the roots than in the leaves (Figure 1B). After growing in $\mathrm{Mn}$ media, MDA increased by about three times in the leaves and by about $1.5-2$ times in the roots of both wheat cultivars. Cultivation on $\mathrm{Mn}+\mathrm{Se}$ media diminished MDA values in all tested objects, as compared with Mn-only conditions, except for cv. Nimfa leaves, where no significant differences between $\mathrm{Mn}+\mathrm{Se}$ and $\mathrm{Mn}$ treatment were found. $\mathrm{Cv}$. Nimfa plants grown on Se-only media had similar MDA levels to controls in both leaves and roots, while in cv. Alibi a decrease in MDA (vs. control) was registered.

The contents of soluble sugars and starch are presented in Table 2. Control leaves of both cultivars contained similar levels of starch, while significantly higher values of soluble sugars were found in cv. Alibi. In Mn-only media, an increase in the level of both simple and compound carbohydrates was indicated. It was especially visible for soluble sugars, the amount of which spiked five times following the metal treatment. Joint treatment with Mn and Se caused a drop in starch concentration (vs. Mn-only variant) in both cultivars. The presence of Se, as the only supplement to the media, did not significantly affect the concentration of any tested carbohydrates.
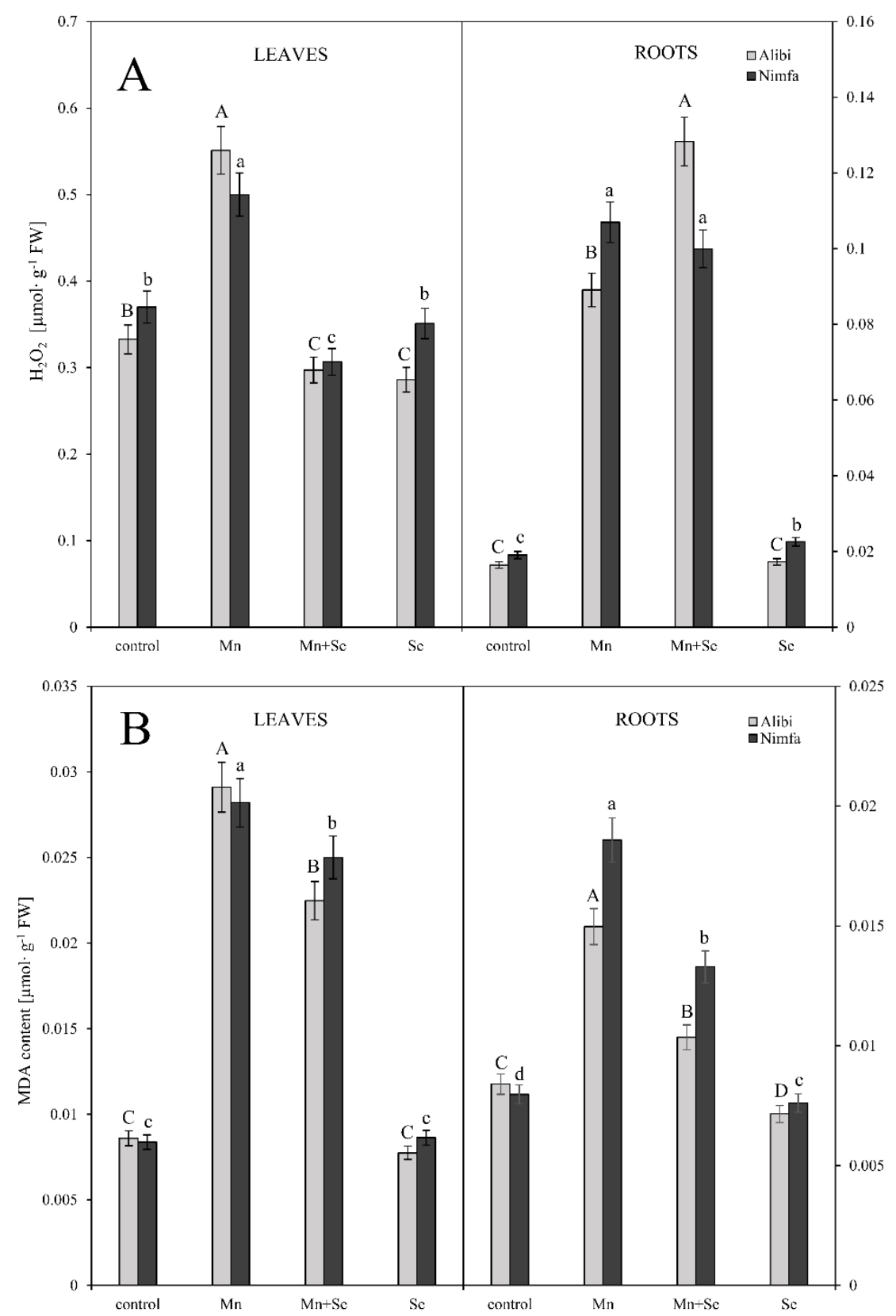
Figure 1. $\mathrm{H}_{2} \mathrm{O}_{2}\left[\mu \mathrm{mol} \mathrm{g}{ }^{-1} \mathrm{FW}\right]-\mathrm{A}$ and malondialdehyde (MDA) $\left[\mu \mathrm{mol} \mathrm{g} \mathrm{g}^{-1} \mathrm{FW}\right]-\mathrm{B}$ content in the leaves and roots of cvs. Alibi and Nimfa in control plants and after treatment with $10 \mathrm{mM} \mathrm{MnCl}$, $10 \mathrm{mM} \mathrm{MnCl}_{2}+15 \mu \mathrm{M} \mathrm{SeCl}_{2}$ and $15 \mu \mathrm{M} \mathrm{SeCl}_{2}$. Data are averages from three independent biological replications \pm SE. The same letters indicate not significant differences between treatments $(p \leq 0.5)$.

Table 2. The sugars content in the leaves of cvs. Alibi and Nimfa in control plants and after treatment with $10 \mathrm{mM} \mathrm{MnCl}_{2}, 10 \mathrm{mM} \mathrm{MnCl}_{2}+15 \mu \mathrm{M} \mathrm{SeCl}_{2}$ and $15 \mu \mathrm{M} \mathrm{SeCl}_{2}$.

\begin{tabular}{|c|c|c|c|}
\hline & & $\begin{array}{r}\text { Soluble sugars } \\
{\left[\mathrm{mg} \cdot \mathrm{g}^{-1} \mathrm{DW}\right]} \\
\end{array}$ & $\begin{array}{r}\text { Starch } \\
{\left[\mathrm{mg} \cdot \mathrm{g}^{-1} \mathrm{DW}\right]} \\
\end{array}$ \\
\hline \multirow{4}{*}{\begin{tabular}{l}
07 \\
\hdashline \\
\hdashline \\
\hdashline
\end{tabular}} & control & $0.127 \pm 0.011^{\mathrm{c}}$ & $0.390 \pm 0.015^{\mathrm{d}}$ \\
\hline & $\mathrm{Mn}$ & $0.537 \pm 0.028^{a}$ & $0.624 \pm 0.037^{\mathrm{a}}$ \\
\hline & $\mathrm{Mn}+\mathrm{Se}$ & $0.463 \pm 0.030^{b}$ & $0.611 \pm 0.035^{b}$ \\
\hline & $\mathrm{Se}$ & $0.136 \pm 0.010^{\mathrm{d}}$ & $0.404 \pm 0.026^{\mathrm{c}}$ \\
\hline \multirow{4}{*}{ 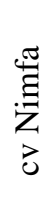 } & control & $0.101 \pm 0.009^{c}$ & $0.395 \pm 0.014^{c}$ \\
\hline & $\mathrm{Mn}$ & $0.621 \pm 0.034^{\mathrm{a}}$ & $0.625 \pm 0.033^{a}$ \\
\hline & $\mathrm{Mn}+\mathrm{Se}$ & $0.420 \pm 0.023^{b}$ & $0.608 \pm 0.029^{b}$ \\
\hline & $\mathrm{Se}$ & $0.121 \pm 0.010^{c}$ & $0.337 \pm 0.020^{\mathrm{d}}$ \\
\hline
\end{tabular}

Data are averages from three independent biological replications \pm SE. The same letters indicate not significant differences between treatments registered separately for each wheat genotype $(p \leq 0.5)$

\subsection{Microscopic observations and analysis of DNA methylation}

Microscopic observations after staining with tolouidine blue revealed numerous chloroplasts in the mesophyll cells of both cultivars grown under control conditions (a representative example is shown in Figure 2A). Figure 2A' shows chloroplasts localized under the membrane uniformly stained with toluidine blue. The unstained areas of the plastids indicate the presence of starch grains. Mn induced visible changes in the chloroplasts, as it boosted starch accumulation and the formation of amyloplasts in mesophyll cells (Figure 2B, C, D). In cv. Alibi the response varied widely, ranging from slight changes in the plastids where starch accumulated (Figure $2 \mathrm{~B}^{\prime}$ ) to complete degeneration of the leaves with numerous amyloplasts in their cells (Figure 2C, $\mathrm{C}^{\prime}$ ). In cv. Nimfa, the vast majority of plastids were changed and accumulated starch (Figure 2D, $\mathrm{D}^{\prime}$ ).

In $\mathrm{Mn}+$ Se variants, plastids in cv. Alibi were mainly amyloplasts (Figure 2E') or small, nearly uniformly colored structures (Figure 2E"). In cv. Nimfa, only amyloplasts were found in the cells of the assimilation parenchyma (Figure 2F, F'). The presence of Se did not change the microscopic image of the leaves in any of the cultivars, which was the same as that recorded for the control (data not shown). 


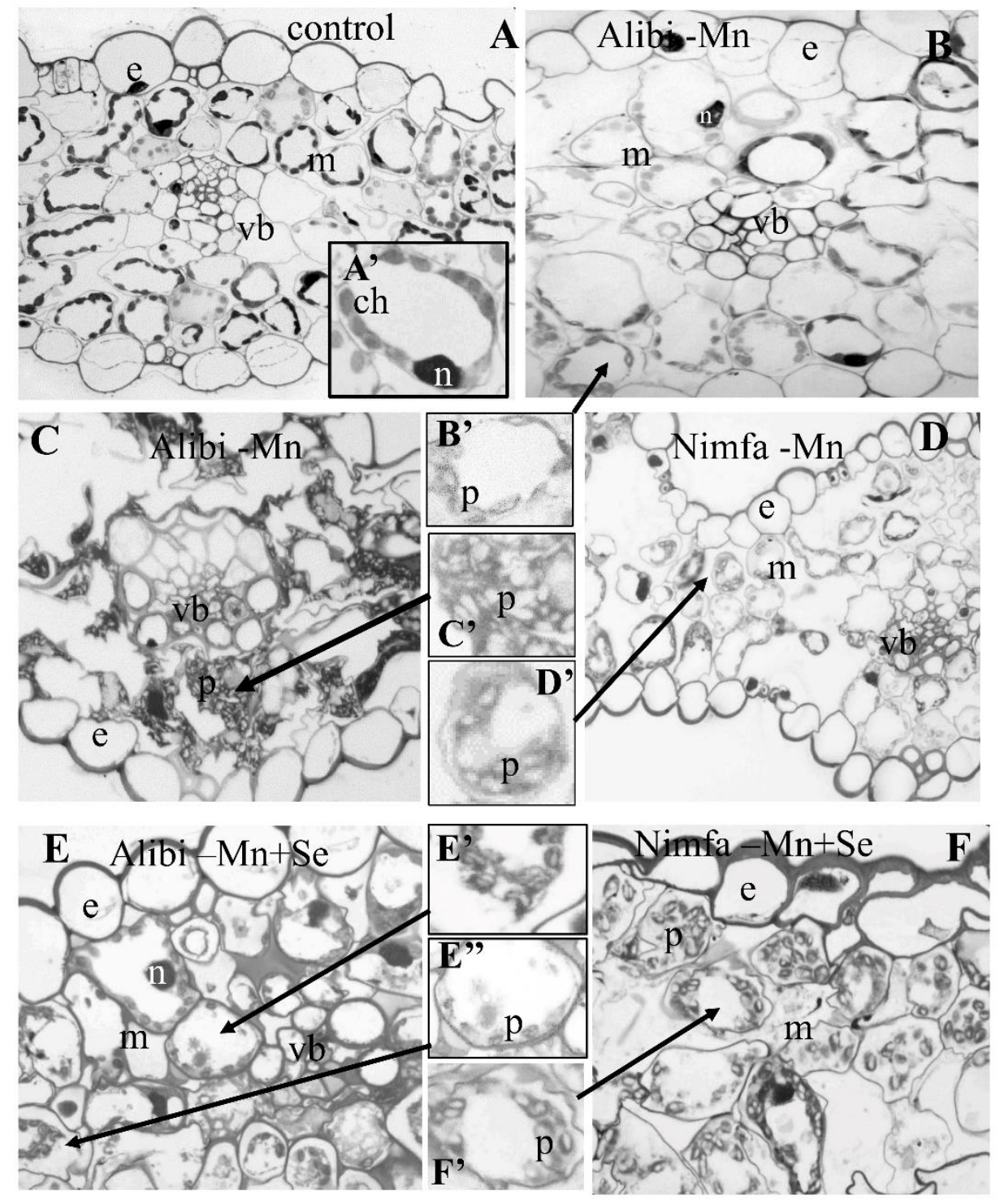

Figure 2. Micrographs of sections of wheat leaves grown under control conditions and after treatment with $10 \mathrm{mM} \mathrm{MnCl}_{2}$ and $10 \mathrm{mM} \mathrm{MnCl}_{2}+15 \mu \mathrm{M} \mathrm{SeCl}_{2}$. e - epiderm, $\mathrm{m}$ - mesophyll cells, vb vascular bundle, ch - chloroplast, $\mathrm{p}$ - plastid, $\mathrm{n}$ - nucleus.

In the leaves of both wheat cultivars, 5-metC was localized in the cell nuclei of all tissues, i.e. in the epidermis, assimilation mesophyll and vascular bundle (Figure 3). There were no significant differences in the nucleus signal intensity in the control leaves (Figure 3A, B) and those grown in the presence of Mn (Figure 3C, D) and Mn+Se (Figure 3E, F). Unexpectedly, microscopic analysis of these sections revealed that Mn uptake resulted not only in starch accumulation in mesophyll plastids. The membranes of the transformed plastids showed autofluorescence, which may indicate changes in their structure (Figure $\left.3 C^{\prime}, D^{\prime}\right)$. In either cultivar, chloroplasts observed in the control mesophyll cells did not show autofluorescence (Figure 3A, B). These changes in plastids were also seen in the leaves of plants grown in the presence of $\mathrm{Mn}+\mathrm{Se}$ (Figure $3 \mathrm{E}^{\prime}, \mathrm{F}^{\prime}$ ). In both cultivars, amyloplasts (Figure $3 \mathrm{E}$ and E', 3F and F') were mainly localized in the cells of the assimilation parenchyma. 

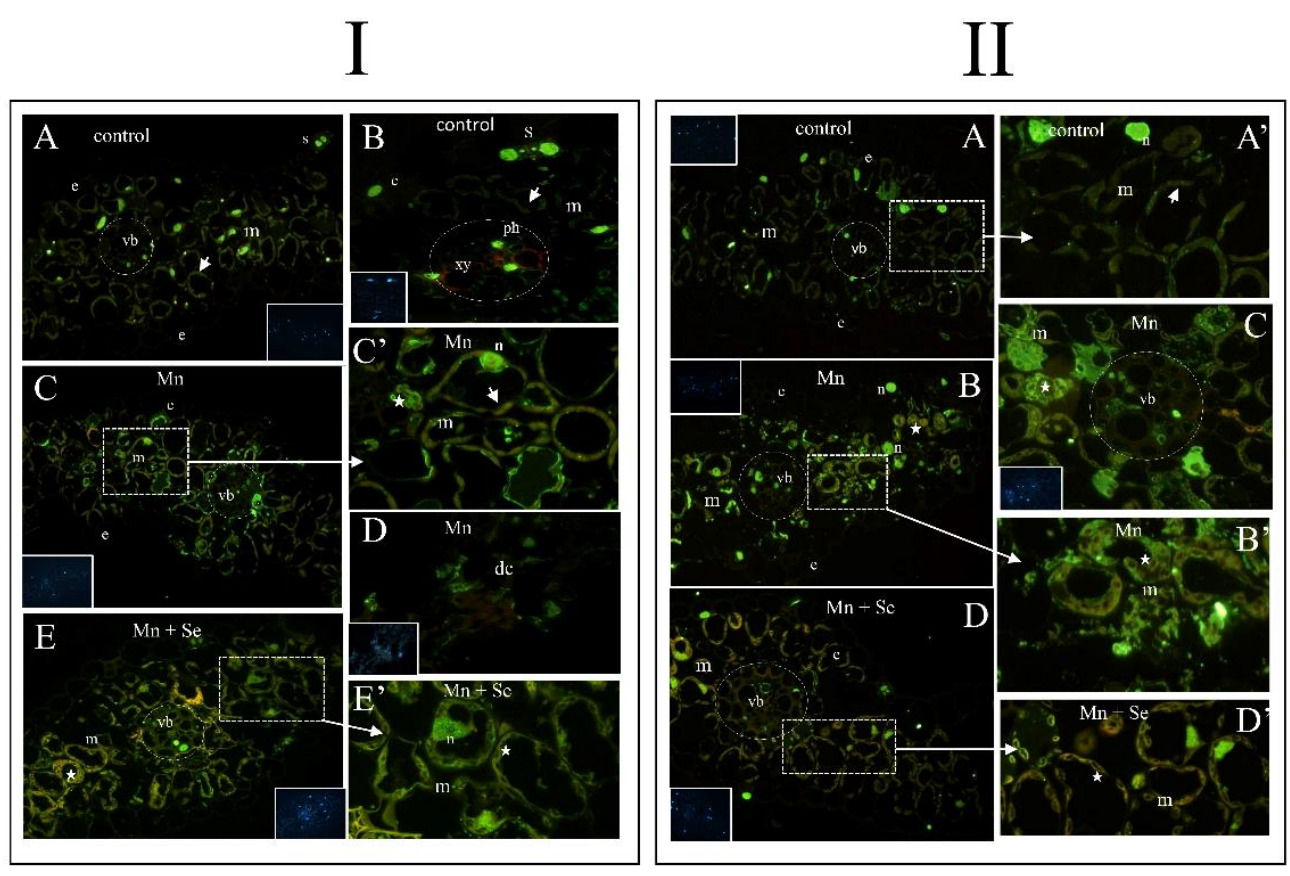

Figure 3. 5-metC localization in cvs. Alibi (I) and Nimfa (II) leaves (circle - vascular bundle, insert - DAPI) x 400. e - epiderm, $\mathrm{m}$ - mesophyll cells, vb - vascular bundle, xy - xylem, ph phloem, s-stomata, $\mathrm{n}$ - nucleus.

Microscopic observations of the control roots (Figure 4A) revealed similar anatomy for both cultivars, with the growth apex surrounded by cap cells, and the meristem composed of rows of cuboid-shaped cells (Figure $4 \mathrm{~A}^{\prime}, \mathrm{A}^{\prime \prime}$ ). Above those, there was a zone of cell extension and differentiation with procambium and procortex layers. In Mn treated plants, the root anatomical structures showed significant differences between the cultivars. In cv. Alibi roots (Figure 4B), the meristematic cells did not have a regular shape (Figure 4B") and the apex was surrounded by a smaller number of cap cells, often with irregular shapes and deformed nuclei. Moreover, the area between the meristem and the zone of differentiation comprised groups of oval-shaped cells that were larger than the surrounding cells and absent in the control (Figure $4 \mathrm{~B}^{\prime}$ ).

Mn uptake led to drastic anatomical changes in cv. Nimfa roots (Figure 4C). These changes were often accompanied by degeneration of major growth apexes. In such roots, numerous cap cells were damaged and the meristematic cells were of abnormal shapes without visible nuclei (Figure 4C'). Additionally, a characteristic group of compact, small cells with large nuclei at the meristem differentiation border was found (Figure 4C'), which was not observed in the control roots. When Mn was provided together with Se, the anatomy of the root growth apex in cv. Alibi (Figure 4D) and cv. Nimfa (Figure 4E) was more similar to the control, and there were no distinguished groups of cells above the meristem. In cv. Alibi, the meristematic cells were of correct shape (Figure 4D'), whereas irregularly shaped cells but with visible nuclei were still present in cv. Nimfa (Figure 4E'). 


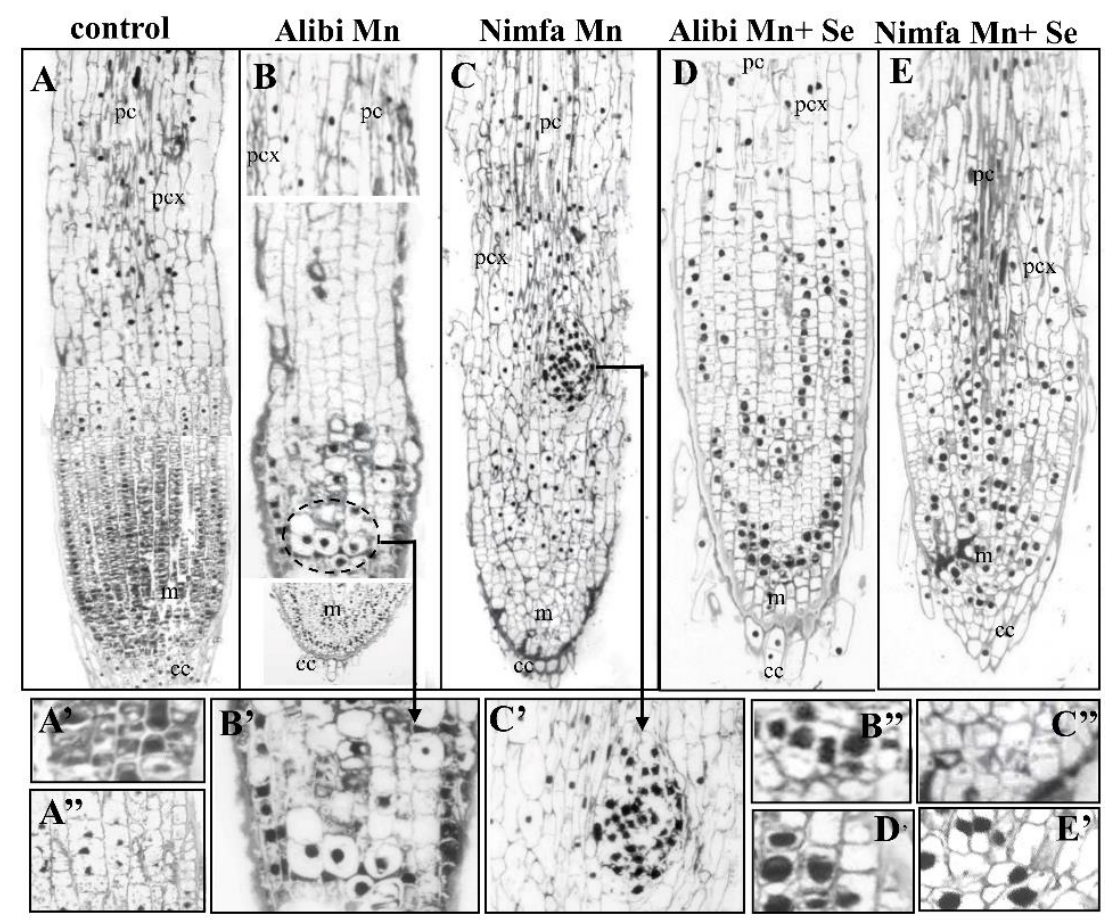

Figure 4. Microscopic observation of wheat roots grown under control conditions and after treatment with $10 \mathrm{mM} \mathrm{MnCl}_{2}$ and $10 \mathrm{mM} \mathrm{MnCl}_{2}+15 \mu \mathrm{M} \mathrm{SeCl}_{2}$. cc - cap cells , m- meristem, pc procambium, pcx -procortex.

In the roots a similar pattern of 5-metC localization (Figure 5.I.A - C) and levels (Figure $6 \mathrm{~A}$ and $6 \mathrm{~B}$ ) was observed in the plants grown under control conditions. A very weak signal was localized in the meristematic and cap cells (Figure 5.I.A). A successive increase in 5-metC was found in the nuclei of cells that entered the differentiation and elongation pathway (Figure 5.I.B and C, Figure 6A and B). In the root elongation zone, the strongest signal was detected in the nuclei of the cells of the differentiating vascular cylinder (Figure 5.I.C). No signal was localized in control material, incubated without anti-5-metC antibodies (data not shown).

In the roots of $\mathrm{cv}$. Alibi grown in the presence of Mn the increase in DNA methylation was observed from the differentiation zone to cell elongation zone, similarly as in control (Figure 5.II.A - C and Figure 6A). In the cap and meristematic cells, DNA was only slightly more methylated than in control (Figure 6A). However, the tissues exhibiting anatomical abnormalities (Figure 4) showed also changes in their DNA methylation pattern. In the cap zone the enhanced signal was visible only in single cells (Figure 5.II.A), while the group of oval-shaped cells, not present in control (Figure $4 \mathrm{~B}^{\prime}$ ), showed lower level of 5-metC than the surrounding cells (Figure 5.II.B, Figure 6A - "different cells"). The elevated level of 5-metC was detected only in the cells on the procambium-procortex border (Figure 5.II.B). In the elongation zone, the cells were irregular, some with no visible nuclei, and some with nuclei with a strong 5-metC signal (Figure 5.II.C). 


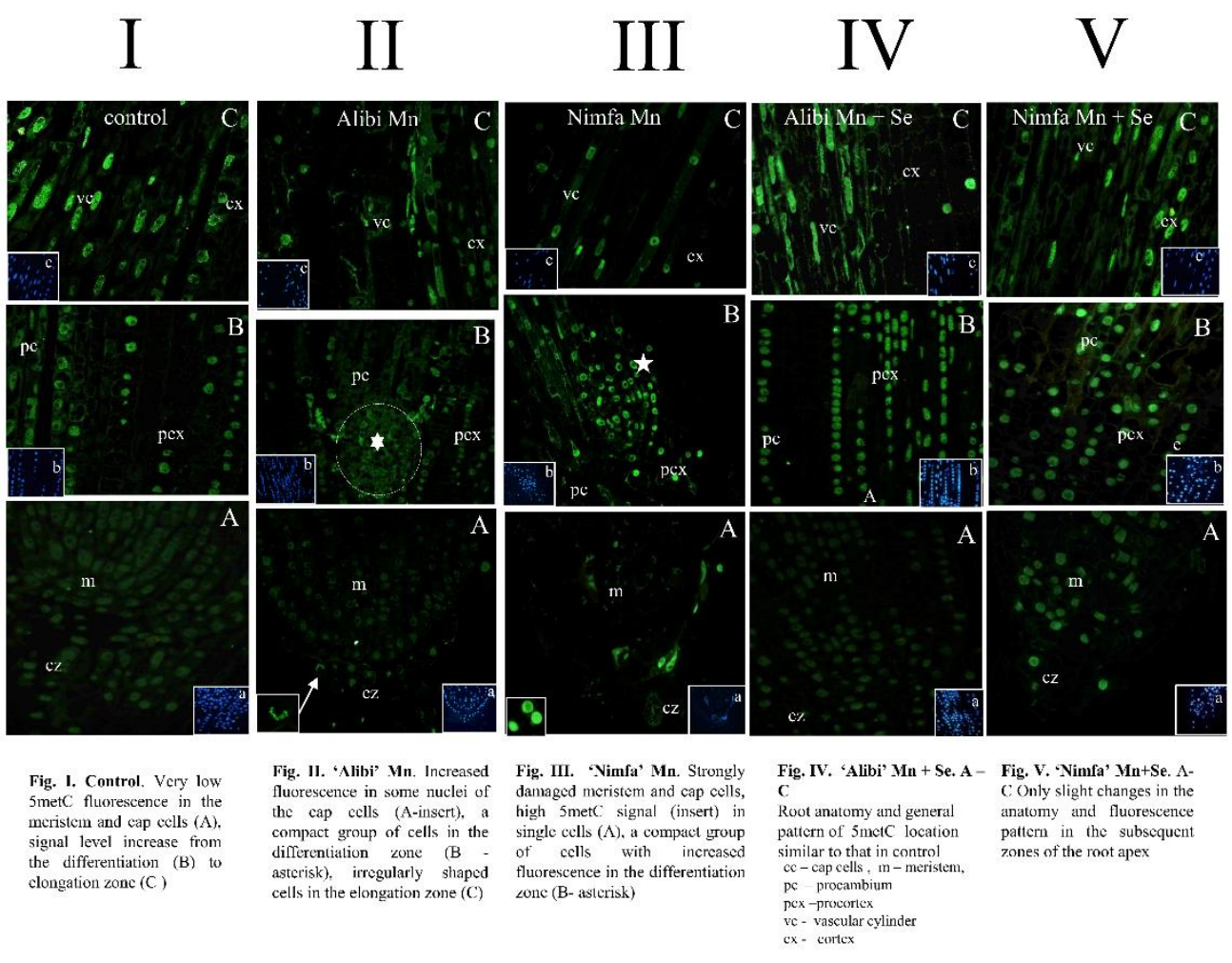

Figure 5. 5-metC localization in the cells of the root growth apex. A - meristem and cap cells, Bdifferentiation zone, $\mathrm{C}$ - elongation zone, a-c DAPI. $x 400$

Mn uptake leading to anatomical changes in cv. Nimfa roots (Figure 4) was also reflected in 5-metC signal intensity in the nuclei (Figure 5.III.A - C, Figure 6B). A significantly stronger signal was detected in the damaged cells of the root apex, i.e. the cap cells with irregular shapes and deformed nuclei and single meristematic cells with nuclei still present (Figure 5.III.A). Additionally, higher level of 5-metC was found in the specific group of small cells with highly condensed DNA (Figure $4 C^{\prime}$ ) on the meristem - differentiation zone border (Figure 5.III.B, Figure 6B - "different cells").

Cultivation of plants in the presence of $\mathrm{Mn}+$ Se prevented the previously observed disturbances in the root tissue differentiation (Figure 4 and Figure 5.IV.A - C and 5.V. A C). In cv. Alibi the level of DNA methylation in the meristem and cap zones was similar to that of the control (Figure 5.IV.A, Figure 6A). In cv. Nimfa, in which the anatomy of these root zones was slightly impaired in some roots (Figure 4.E), the level of 5-metC was also slightly higher than in control (Figure 5.V.A, Fig. 6B). In both cultivars, no significant disturbances in the differentiation and root elongation zones were found (Figure 5.IV.B C, 5.V.B - C) and, similarly to the control, a progressive increase in DNA methylation was observed in the differentiating cells (Figure 6A and B).

A quantitative assessment of 5-metC level is shown in Figure 6. In both cultivars, regardless of the treatment, we found an increase in methylation level from the root cap to the differentiation zone. Mn presence generally enhanced methylation intensity. In cv. Alibi, significant changes were restricted to the differentiation zone, while in cv. Nimfa they occurred throughout the root apex. A particular increase in 5-metC was recorded in the root cap (ca. three-fold) and in the apical meristem (ca. 2.5-fold). Under Mn+Se conditions, methylation levels were similar to those found in the control. 

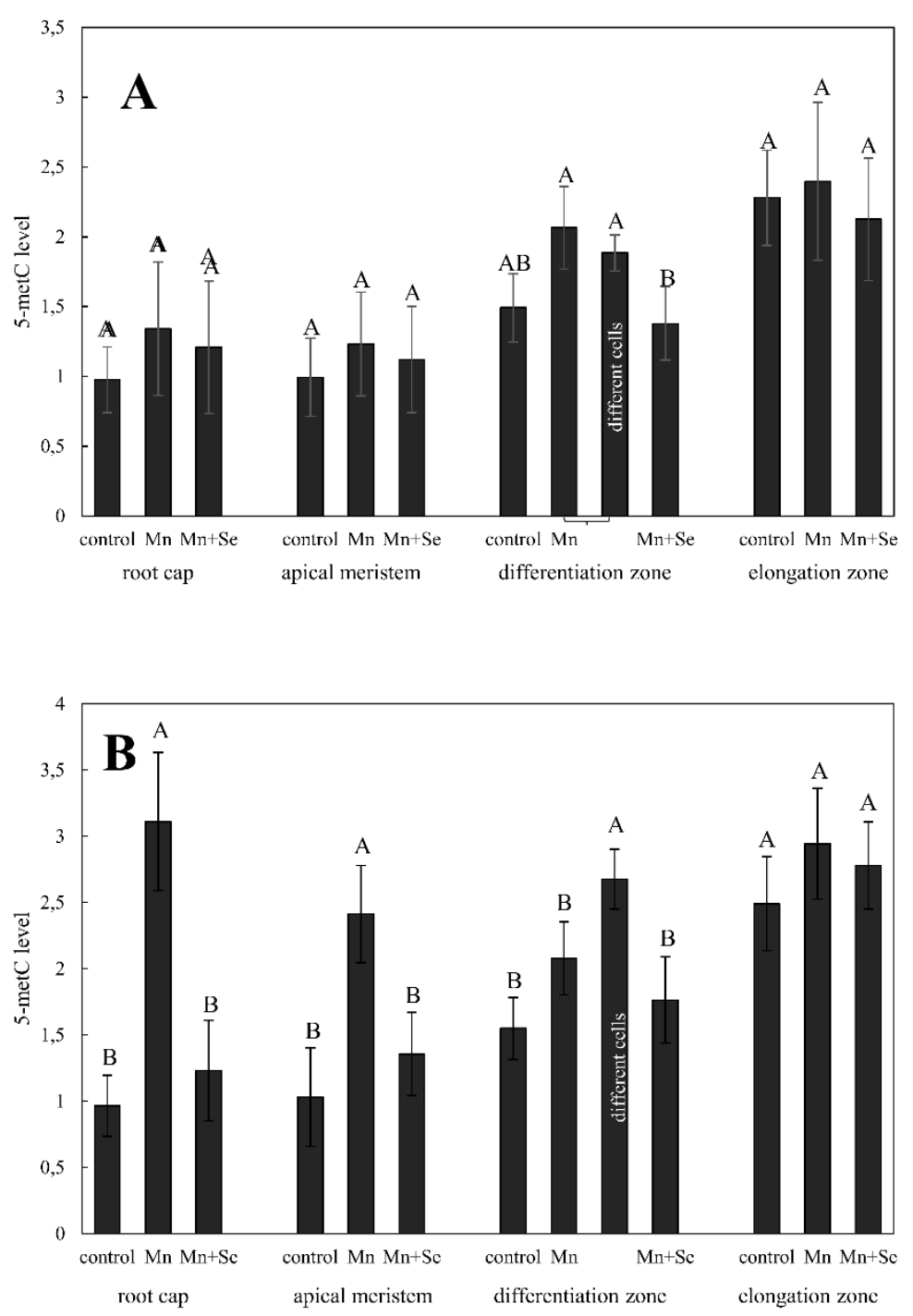

Figure 6. 5-metC level in the cells of cv. Alibi (A) and Nimfa (B) root growth apex (control, Mn manganese, $\mathrm{Mn}+\mathrm{Se}-$ manganese +selenium). Data are averages from three independent biological replications \pm SE. The same letters indicate not significant differences between treatments $(p \leq 0.5)$.

The analysis of DNA methylation profiles using MSAP method showed no changes in the band pattern in the leaves collected from control plants and from those grown in the presence of $\mathrm{Mn}, \mathrm{Mn}+\mathrm{Se}$ or Se (data not shown). In this organ, only two types of loci were found: monomorphic and polymorphic of type I, which reflected a particular methylation status of cytosines in CCGG sequence recognized by HpaII and MspI restriction enzymes, but unrelated to methylation changes triggered by growth conditions.

Contrary to that, in the roots we found 101 polymorphic loci of type II, representing differences in methylation of CCGG sites. One of these loci was polymorphic between cvs. Alibi and Nimfa, but did not show any methylation changes between the treatments: the bands were present in all cv. Alibi samples and absent in all cv. Nimfa samples, and thus this locus was not taken into account in further analysis. The other two loci also distinguished the cultivars of Alibi and Nimfa. In the first locus, absent in cv. Nimfa, the bands were present in both restriction combinations in cv. Alibi roots treated with a combination of Mn and Se. The second locus was absent in cv. Alibi, whereas in all cv. Nimfa samples the bands were present after HpaII/EcoRI digestion only. The bands in the remaining loci were present in both cultivars and represented various patterns of MSAP profiles. 
Altogether 100 polymorphic loci were used to calculate the proportion of demethylation (de-Met) and de novo methylation (de novo-Met) of cytosines at CCGG sites. Additionally, the proportion of symmetric methylation changes of cytosines in CG and CHG context (where $\mathrm{H}$ represents internal cytosine in CCGG sequence) was estimated taking into account: (i) demethylation of CHG context (de-Met-CHG), (ii) demethylation of CG context (de-Met-CG), (iii) de novo methylation of CHG context (de novo-Met-CHG), and (iv) de novo methylation of CG context (de novo-Met-CG).

The methylation status of CCGG sites in cv. Alibi and cv. Nimfa roots was comparable and changed in a similar manner in all treatments in both cultivars (Table 3). A higher proportion of demethylation than de novo methylation events was detected at CCGG sites after $\mathrm{Mn}$ and $\mathrm{Mn}+$ Se application regardless of the genotype. At the same time, more changes in methylation status were noticed for the joint treatment with $\mathrm{Mn}$ and Se than for Mn-only treatment. Plant cultivation on the media supplemented with Se alone resulted in the lowest proportion of changes with similar number of demethylation and de novo methylation events. An analysis of the proportion of methylation changes at symmetric cytosines also showed a greater percentage of de-methylation than de novo methylation events at CHG and CG sites following Mn treatment. Under Mn + Se conditions, the proportion of all tested methylation events increased, especially in the context of de novo methylation of CHG sites. However, the presence of Se only reduced the amount of methylation changes in comparison with the controls, particularly of demethylation or de novo methylation of CHG context (Table 3).

Table 3. Comparison of methylation status in cvs. Nimfa and Alibi root samples expressed as the percentage of methylation changes between control samples (C) and each of the treatments (Mn only, $\mathrm{Mn}+\mathrm{Se}$ and Se only). The data are based on all polymorphic MSAP loci.

\begin{tabular}{lcccccc}
\hline & \multicolumn{3}{c}{ Nimfa } & \multicolumn{3}{c}{ Alibi } \\
\cline { 2 - 7 } Type of the event & C vs & C vs & C vs & C vs & C vs & C vs \\
& Mn & Mn+Se & Se & Mn & Mn+Se & Se \\
\hline de-Met & 20.18 & 27.70 & 10.80 & 21.06 & 29.70 & 10.32 \\
de novo-Met & 12.16 & 18.01 & 11.01 & 12.15 & 18.32 & 11.94 \\
\hline \hline de-Met-CHG & 9.06 & 15.32 & 1.44 & 9.72 & 16.83 & 1.01 \\
de-Met-CG & 11.12 & 12.38 & 9.36 & 11.34 & 12.87 & 9.31 \\
de novo-Met-CHG & 3.21 & 8.82 & 1.85 & 3.24 & 9.16 & 2.23 \\
de novo-Met-CG & 8.94 & 9.19 & 9.16 & 8.91 & 9.16 & 9.72 \\
\hline
\end{tabular}

When the analysis was limited to the 20 polymorphic loci that represented the genotype specific changes in the methylation events, some minor differences in the proportion of methylation changes were noticed as compared with those described above (Table 4). The combined $\mathrm{Mn}+\mathrm{Se}$ treatment resulted in a higher proportion of de novo methylations of CCGG sequences in cv. Nimfa roots. Also, Se-only treatment increased the proportion of methylation changes in cvs. Nimfa and Alibi, including the higher number of demethylation or de novo methylation events at CHG and CG context, except for demethylations at $\mathrm{CHG}$ in cv. Alibi roots.

Table 4. The comparison of methylation status in cvs. Nimfa and Alibi root samples expressed as the percentage of methylation changes between control samples $(C)$ and each of the treatments (Mn only, Mn+Se and Se only). The data are based on the 20 polymorphic loci that represent the genotype specific changes in the methylation events.

\begin{tabular}{lll}
\hline Type of the event & Nimfa & Alibi \\
\hline
\end{tabular}




\begin{tabular}{lcccccc}
\hline & $\begin{array}{c}\text { C vs } \\
\text { Mn }\end{array}$ & $\begin{array}{c}\text { C vs } \\
\text { Mn+Se }\end{array}$ & $\begin{array}{c}\text { C vs } \\
\text { Se }\end{array}$ & $\begin{array}{c}\text { C vs } \\
\text { Mn }\end{array}$ & $\begin{array}{c}\text { C vs } \\
\text { Mn+Se }\end{array}$ & $\begin{array}{c}\text { C vs } \\
\text { Se }\end{array}$ \\
\hline de-Met & 17.50 & 15.91 & 16.25 & 22.37 & 25.00 & 13.07 \\
de novo-Met & 10.63 & 19.32 & 15.00 & 10.53 & 20.83 & 19.89 \\
\hline \hline de-Met-CHG & 7.50 & 6.82 & 6.25 & 11.18 & 13.69 & 3.41 \\
de-Met-CG & 10.00 & 9.09 & 10.00 & 11.18 & 11.31 & 9.66 \\
de novo-Met-CHG & 2.50 & 9.09 & 7.50 & 2.63 & 10.71 & 9.09 \\
de novo-Met-CG & 8.13 & 10.23 & 7.50 & 7.89 & 10.12 & 10.80 \\
\hline
\end{tabular}

\section{Discussion}

\section{Biochemical analysis}

Typical symptoms of Mn toxicity in plants include brown spots, with the intensity of color depending on the accumulated ion and susceptibility of cultivars [44]. In our study, the tissue browning indicated that the applied dose of Mn was stressful for both tested cultivars, and slightly more intense in cv. Alibi. Greater differences between the cultivars involved the response of their root systems. The larger loss of weight (in relation to the control) noted in cV. Alibi, may suggest that for this cultivar Mn treatment was more stressful than for cv. Nimfa. This conclusion is consistent with the generally accepted assumption that the decrease of tissue mass is an indicator of the intensity of toxic effects in plants [45]. Selenium used at the selected concentration did not affect the appearance of tissues (macroscopic and microscopic observations) or their fresh weight. However, increased weight of both leaves and roots (vs. Mn-only treatment) and reduction of visual effects of Mn, indicate possible Se-induced protection against Mn stress. Thus, our data suggest the possibility of using Se to improve plant resistance to Mn excess.

Yao et al. [46], who analyzed Mn level in grapes, indicated that depending on the cultivar, either more of this element was retained in the roots or was distributed to the leaves, even in the resistant plants. It is suggested that the accumulation of greater amounts of stressors (metal ions, toxins) in tissues of susceptible cultivars, as compared with resistant ones, is the main cause of their greater damage [33,47]. Also, in the studies of Millaleo et al. [48], the correlation between Mn content in selected organs and their destruction occurred even in the same genotype. In our experiments, greater amount of $\mathrm{Mn}$ accumulated in the root system than in the leaves of the tested plants may indicate that the roots were more sensitive to Mn stress. However, higher level of Mn (in both leaves and roots) was found in cv. Nimfa than in cv. Alibi, even though cv. Alibi responded with a greater weight loss. Moreover, the addition of Se (suggested above as a potential protection), additionally enhanced Mn accumulation. According to Yao et al. [46] it was showed that depending on the variety, either more of this element was retained in the roots or was distributed to the leaves, even in the resistant plants. Thus, it seems that it cannot be unequivocally concluded that greater accumulation of $\mathrm{Mn}$ is the only indicator that differentiates sensitivity of the studied cultivars to this stressor. Also, specific properties of the membranes of the investigated cultivars should be taken into account (especially permeability, depending on the content of non-saturated lipids and the presence of ion transporters). Yang et al. [49] researched specific transporters participating in Mn translocation. Independently of the uptake by Mn-transporters, Mn can be also absorbed by transporters of other ions of similar value and size.

The change in MDA is considered an indicator of the membrane permeability and fluidity, which depend on the content of non-saturated fatty acids [2]. A decrease in lipid unsaturation (recorded as an increase in MDA value) may increase the membrane stiffness and, consequently, modify the activity of membrane transporters and ion channels. The decrease in the nutrient content in the presence of Mn correlated with a decrease in membrane permeability, indirectly shown as an increase in MDA concentration. Significant 
negative correlations ( $\mathrm{r}=-0.802$ to $\mathrm{r}=-0.991, \mathrm{p}<0.05)$ between accumulation of the investigated elements in the leaves and Mn uptake (both alone and in combination with Se) suggested "blocking the transport" of the other elements under Mn stress. However, in the roots of both cultivars, also positive correlations of Mn with $\mathrm{Zn}, \mathrm{P}$ and S (r=0.844 to r=0. 999; $\mathrm{p}<0.05)$, and additionally with $\mathrm{Ca}(\mathrm{r}=0.951, \mathrm{p}<0.05)$ for $\mathrm{Mn}+\mathrm{Se}$ variant were shown. Moreover, in the roots of cv. Nimfa, a correlation between Mn and Ca ( $r=0.997)$ was noted when Mn was administered alone. The reduced uptake of the studied elements under Mn stress was demonstrated earlier in the leaves of various plant species [50, 51]. Also, in chloroplasts of wheat seedlings, diminished accumulation of $\mathrm{Zn}, \mathrm{Cu}, \mathrm{Fe}, \mathrm{Mg}$ and $\mathrm{Ca}$ was shown under Mn stress [33]. Altered concentrations of these nutrients may disturb metabolic processes and consequently curb plant growth as manifested in a decrease of fresh weight in the presence of $\mathrm{Mn}$.

Interestingly, the increased uptake of $\mathrm{Ca}$ by the roots of both cultivars under $\mathrm{Mn}+\mathrm{Se}$ treatment, and in cv. Nimfa roots under Mn stress was noted. The importance of Ca ion as a signal molecule (so-called "secondary messenger"), under stress was described in numerous papers [52,53]. As revealed by White et al. [54], this ion is uptaken from a growth media through plasma membrane channels located in the roots. This may explain why the increase in its amount was evident in the roots. The presence of Se ions can also activate calcium channels partly blocked by $\mathrm{Mn}$, as shown for another stressor [32]. Additionally, in Mn-damaged roots, extra Ca uptake stimulated by Se may contribute to "rebuilding" of the tissues. The increase in the concentration of Ca ions during the initiation of developmental processes was demonstrated in many studies $[52,55,56]$. This role of Ca may explain the appearance of meristematic centers in the roots of cv. Nimfa treated with Mn (Figure 4). Ca influx may be also regulated by the generation of ROS during stress reactions [57]. Among $\mathrm{ROS} \mathrm{H}_{2} \mathrm{O}_{2}$, similarly to $\mathrm{Ca}$, is the molecule recognized as an important element of cell signaling [57], independently of its ability to oxidize biomolecules and disrupt their functioning. Thus, a significant increase in $\mathrm{H}_{2} \mathrm{O}_{2}$ concentration in the presence of $\mathrm{Mn}$, especially visible in the roots (as compared with control), may indicate both greater intensity of stress in these organs, but also, as in the case of $\mathrm{Ca}$, its involvement in "chemical signaling process" leading to limited tissue destruction (roots).

Microscopic observations and analysis of DNA methylation

Special function of the roots was indicated by the fact that microscopic observations of the leaf structures showed smaller damage of these organs in the presence of Mn than the roots. Main changes in the leaf tissues involved chloroplast formation and the amount and distribution of starch in these organelles. The quantitative changes and redistribution of starch in chloroplasts were found under various environmental stressors [58]. Our earlier studies also showed a genotype resistance-dependent increase in the accumulation of this polysaccharide [33]. Small differences regarding the chloroplasts modification of the investigated plants treated with $\mathrm{Mn}$, were mainly registered as changes in distribution of these organelles in the cells. Starch distribution within the chloroplasts (Figure 2) correlated with the increase in its concentration, registered biochemically (Table 2). It may indicate a comparable susceptibility of both cultivars to Mn. However, in cv. Alibi we also found partly damaged leaves with changes in the chloroplasts typical of less tolerant plants. The stimulation of protective mechanisms under Mn stress was evidenced by an almost twofold increase in the concentration of soluble sugars in both cultivars. These molecules are regarded as osmoprotective agents, the accumulation of which may reduce negative effects of many stressors [59]. Relatively high level of soluble sugars accompanied by reduced starch content and smaller microscopically visible damage in the leaves may confirm the involvement of Se in the protective reactions against Mn stress, as suggested based on the experiments described above.

Larger anatomical differences between the examined objects exposed to Mn were observed in the roots. In cv. Alibi, changes in the shape of meristematic cells were noted, and a reduction in the number and extent of structural damage of the cap cells, as well as the appearance, in the area between the meristem and the differentiation zone, of additional (compared to the control) groups of oval cells, larger than the surrounding cells (Figure 
$\left.4 \mathrm{~B}^{\prime}\right)$. Their presence may indicate a potential change in the direction of cell differentiation in this area of the root. Moreover, in the elongation zone, cells were often irregular in shape, some without visible nuclei. Such modifications may suggest that Mn induced faster apoptosis of the cap cells and impaired differentiation of root tissues. In cv. Nimfa roots treated with $\mathrm{Mn}$ we found a decrease in the number of cap cells in comparison with control (Figure 4C). A characteristic change, observed only in this cultivar, was the presence of a group of small cells, with large nuclei and condensed chromatin, visible at the border of the meristem and differentiation zone (Figure 4C'). Presumably, these are procortex cells that differentiate into a new root apex. The formation of the new root apexes in cv. Nimfa could be an element of plant defense mechanisms allowing for plant regeneration even after death of the primary roots. It may be related to the increase in Ca content in these objects observed in the presence of $\mathrm{Mn}$, as suggested above. Independently of the stress reactions induced by $\mathrm{Mn}$, the protective role of Se was also revealed in anatomical observations of the roots, as a reduction of changes caused by the presence of $\mathrm{Mn}$.

The anatomical modifications induced by Mn in the leaves of the studied cultivars, mainly in the form of starch accumulation in plastids, were not accompanied by changes in DNA methylation determined based on the global level of 5-metC detected with immunocytochemical method and the analysis of methylation status of CCGG sequences with MSAP method.

Contrary to that, our analysis of wheat roots indicated that the global 5-metC level varied in different root zones and tissues. Kumpf et al. [60] reported a very low level of DNA methylation in dividing, undifferentiated meristematic cells and short-lived cap cells, which soon enter the path of apoptosis. However, we showed for the first time a progressive increase in DNA methylation from dividing meristematic cells to differentiating and elongating cells of the vascular cylinder and cortex, as measured by the global 5 -metC level. The role of DNA methylation in the processes of plant tissue differentiation is well known $[61,62]$. Elevated levels of 5-metC in the meristem and cap cells in the presence of Mn likely reflect the process of their apoptosis. The higher 5-metC content in cv. Alibi was observed only in a few cells of the cap and meristem, while in cv. Nimfa it was found in all visible cell nuclei. We may then conclude that in this cultivar Mn absorption could lead to cell apoptosis and death of the main growth apex. The phenomenon of DNA methylation during apoptosis was described in Danio rerio cells subjected to malnutrition stress [63].

Moreover, microscopic observations indicated that in both cultivars, cells of the differentiation zone had the potential ability to change their differentiation pattern in the presence of $\mathrm{Mn}$, probably towards formation of an additional growth apex. This process seemed to be faster in the cultivar Nimfa, in which Mn stress strongly damaged meristematic root cells. Mn uptake resulted in faster apoptosis of the cap cells and impaired differentiation of root tissues. These processes were accompanied by changes in DNA methylation. Our study is the first to report a progressive increase in DNA methylation from dividing meristematic cells to elongating cells of the axial cylinder and cortex, as measured by global 5-metC level. The increase in 5-metC methylation signals after the treatment with Mn may result from the activation of pathways that counteract the transposon movement. A characteristic feature observed in both cultivars under Mn was the presence of groups of distinct cells in the meristem-differentiation zone. In cv. Alibi they were larger cells (Figure 4B') with slightly reduced 5-metC level (Figure 5IIB, Figure 6A). In cv. Nimfa they were a group of small cells with highly condensed DNA (Figure $4 C^{\prime}$ ) and increased level of DNA methylation (Figure 5IIIB, Figure 6B). It can be assumed that these are cells whose differentiation was altered. Mn induced process of changing the direction of differentiation was likely accompanied by changes in DNA methylation. In cv. Nimfa, with the death of the main grows apex, these cells are probably differentiating into new root apexes. The formation of a new root apex could serve as a defense mechanism for the plant in the event of the main root apex dieback.

Contrary to the increase in cytosine methylation reflected by global level of 5-metC in the root nuclei, our MSAP analysis showed the predominance of demethylation events 
at CCGG sites after Mn and Mn + Se treatments in the roots of both cultivars. These discrepancies may be explained in two ways. The MSAP analysis was based on the homogenized material from the entire root system, thus the results were averaged across all root zones and all tissue types, whereas the quantification of global level of 5-metC was directed to specific zones and tissues. The second possible explanation is related to the resolution of the analysis and the type of sequence context where the methylated cytosine may be present. Here, the MSAP method gives much higher resolution than in situ hybridization, as it allows us to detect the methylation status of sequences located in very close proximity to each other. On the other hand, the MSAP method, which utilizes HpaII and MspI restriction enzymes, is directed for the analysis of CCGG sequences only and in situ hybridization allows for detecting also other sequences with methylated cytosine residues. This kind of explanation seems even more plausible, as it indicates that the stress related to high doses of Mn may preferentially induce de novo methylation of cytosines in other sequence contexts, for example in asymmetric $\mathrm{CHH}$ sites (where $\mathrm{H}$ indicates any nucleotide except for $\mathrm{G}$ ). In many species, the asymmetric $\mathrm{CHH}$ sites are often present in heterochromatin and within or nearby transposons and retrotransposons, which need to be silenced to prevent the instability of the genome [64]. We may therefore hypothesize that the increase in 5-metC methylation signals after the treatment with Mn may result from the activation of pathways that counteract the transposon movement. At the same time our in situ hybridization analysis showed that the addition of Se to the medium with $\mathrm{Mn}$ resulted in similar methylation levels as found in control. This may support the hypothesis of the protective role of Se ions in wheat subjected to high concentration of Mn, as in their presence the activation of the mechanisms of genome stability protection may not be necessary.

Following up on this hypothesis, we may assume that at least some CCGG sequences targeted by the MSAP method may be located in the gene coding regions. It was showed that methylated CG clusters are present in the gene body of many constitutively expressed genes [65], and that methylation of CHG sequences can also correlate with gene expression activation [66]. The demethylation events detected in our MSAP analysis after Mn and $\mathrm{Mn}+$ Se treatments may reflect the necessity of differential regulation of gene expression at particular loci in the presence of these ions. It is also known, however, that the link between methylation level of CG and CHG sites and the level of gene expression is highly gene-specific [66], which mitigates the straightforward interpretation of such results. Nonetheless, the complex changes in DNA methylation patterns that emerge from our study encourage a much deeper analysis based on DNA bisulfide sequencing in order to identify specific genes that may be regulated by differential methylation status in response to $\mathrm{Mn}$ and Se ions. This may support the hypothesis of protective role of Se ions in wheat subjected to high concentration of $\mathrm{Mn}$, as in their presence the activation of the mechanisms of genome stability protection may not be necessary.

\section{Materials and Methods}

\section{Plant material}

Grains of spring wheat (cv. 'Nimfa', cv. 'Alibi'), obtained from a Polish Plant Breeding Station in Strzelce, were sterilized with $80 \%$ ethanol and $10 \%$ perhydrol, and rinsed four times with distilled water. After sterilization the seeds were placed in Petri dishes and germinated for two days, at $20^{\circ} \mathrm{C}$ in darkness. Next, the seedlings were placed individually in the holes of polystyrene discs put on top of the vessels (10 l) filled with $50 \%$ Hoagland medium (1:1; v:v) as a control, or supplemented with $10 \mathrm{mM} \mathrm{MnCl}$ (Mn treatment), $10 \mathrm{mM} \mathrm{MnCl}+15 \mu \mathrm{M} \mathrm{SeCl}_{2}$ (Mn+Se treatment), or $15 \mu \mathrm{M} \mathrm{SeCl}_{2}$ (Se). The seedlings were grown in the hydroponic conditions with a relative humidity 45 - 50\%, light intensity $800 \mu \mathrm{mol}$ (photon) $\mathrm{m}^{-2} \mathrm{~s}^{-1}$ (SQS, Hansatech Ltd, Kings Lynn, United Kingdom), and $16 \mathrm{~h}$ photoperiod $\left(17 / 20^{\circ} \mathrm{C}\right.$ night/day) until the phase of the third leaf. Then the plants were collected, shoots were separated from roots, tissues were weighed and frozen in liquid 
nitrogen for biochemical and MSAP analysis. Microscopic analyzes were carried out in fresh leaves and roots.

\section{Determination of hydrogen peroxide}

One gram of leaves or roots was homogenized with $2 \mathrm{ml}$ of a solution containing 0.25 $\mathrm{ml}$ trichloroacetic acid (TCA) $(0.1 \%$ (w:v) [67]. The homogenate was centrifuged (MPW 251R) at $12,000 \times \mathrm{g}$ for $15 \mathrm{~min}$ at $4^{\circ} \mathrm{C}$. Then $0.5 \mathrm{ml}$ of the supernatant was taken and mixed with $0.5 \mathrm{ml} \mathrm{KI}(1 \mathrm{M})$ and $0.25 \mathrm{ml}$ potassium phosphate buffer $(10 \mathrm{mM}, \mathrm{pH} 7.2)$ at $4^{\circ} \mathrm{C}$. The quantitative determination was performed based on calibration curves for $\mathrm{H}_{2} \mathrm{O}_{2}$ prepared in $0.1 \%$ TCA.

\section{Determination of soluble sugars and starch}

For analyses of soluble sugars, a method described by Janeczko et al. [68] with same modifications was used. About $1 \mathrm{~g}$ of leaves were homogenized with $80 \%$ (v:v) ethanol and the extract was centrifuged at 5,000 $\times \mathrm{g}$ for $10 \mathrm{~min}$, at $4^{\circ} \mathrm{C}$. Then, the supernatant was heated with anthrone $\left(0.2 \mathrm{~g}\right.$ anthrone in $\left.1000 \mathrm{ml} 72 \% \mathrm{H}_{2} \mathrm{SO}_{4}\right)$ for $10 \mathrm{~min}$, and fast cooled to $20^{\circ} \mathrm{C}$. Spectrophotometric measurements (Thermo Scientific Evolution 201/220 UV-Visible) at $\lambda=625 \mathrm{~nm}$ allowed us to determine the content of carbohydrates. For quantitative calculations, a curve with glucose (Sigma Aldrich) as a standard was prepared.

Starch content was detected in leaf samples $(1 \mathrm{~g})$ homogenized with $0.2 \mathrm{M} \mathrm{KOH}$. After heating for $30 \mathrm{~min}$, the samples were cooled and acetic acid was added to neutralize the mixtures. Starch depolymerization into glucose was carried out in a medium with 0.5 unit of $\alpha$-amylase (EC 3211) for $15 \mathrm{~h}$ at $50^{\circ} \mathrm{C}$. After centrifuging at $6,000 \times \mathrm{g}$ for $5 \mathrm{~min}$, glucose content was determined by the anthrone method, as described above.

\section{Malone dialdehyde (MDA) analysis}

One gram of leaves and roots were homogenized in $0.5 \%$ (w/v) TCA (trichloroacetic acid) in a cold room according to Dhindsa et al. [69] and Tobiasz et al. [70]. After homogenization, the samples were centrifuged at $5000 \mathrm{xg}$ for $20 \mathrm{~min}$, at $4{ }^{\circ} \mathrm{C}$ (MPW-351R). Then, $0.25 \%(\mathrm{w} / \mathrm{v})$ TBA (thiobarbituric acid) in $10 \%(\mathrm{w} / \mathrm{v})$ TCA was added into the supernatant and the mixture was heated at $95{ }^{\circ} \mathrm{C}$ for 30 min, quickly cooled on ice, and again centrifuged at $5,000 \times \mathrm{g}$ for $20 \mathrm{~min}$. Absorbance of the supernatant samples was measured at $\lambda=532 \mathrm{~nm}$ and $\lambda=600 \mathrm{~nm}$ using a Thermo Scientific Evolution 201/220 UV-Visible spectrophotometer.

\section{Macro- and micronutrient detection}

Portions (1.2 g) of lyophilized plant material were weighed (with an accuracy of 10-5 g) and mineralized with $6 \mathrm{ml}$ of concentrated nitric acid. Macronutrient content was detected by an inductively coupled plasma optic emission spectrometer ICP OES Optima 2100 (Perkin Elmer) at the following wavelengths: Mn $259.372 \mathrm{~nm}, \mathrm{Mg} 285.213 \mathrm{~nm}, \mathrm{Fe}$ $238.204 \mathrm{~nm}$, Ca $317.933 \mathrm{~nm}, \mathrm{~S} 181.975 \mathrm{~nm}, \mathrm{P} 213.617 \mathrm{~nm}$ in axial plasma observation mode; $\mathrm{K} 766.490 \mathrm{~nm}$ in radial observation mode, and with high argon flow through the monochromator system. Micronutrient content determination was based on Cu63, Zn68 and Fe57 isotopes as standards and inductively coupled plasma mass spectrometry (ICPMS; Elan DRC-e, Perkin Elmer, Shelton, USA) [70].

\section{Microscopic observations and determination of 5-metC localization}

The samples dissected from the leaves an roots were fixed with $4 \%$ paraformaldehyde (Polysciences) and $0.25 \%$ glutaraldehyde (Sigma) in phosphate-buffered saline (PBS), pH 7.2, for $24 \mathrm{~h}$ at $4{ }^{\circ} \mathrm{C}$ and prepared for embedding in BMM resin (butyl methacrylate, methyl methacrylate, $0.5 \%$ benzoyl ethyl ether (Sigma) with $10 \mathrm{mM}$ DDT (Thermo Fisher Scientific)) according to Niedojadlo et al. [71]. The samples were cut on Leica UCT ultramicrotome into serial semithin cross sections $(1.5 \mu \mathrm{m})$, which were collected on Thermo ScientificTM Polysine adhesion microscope slides. The sections were hot stained with methylene blue for 10 minutes. They were flushed several times with distilled water, 
and then sealed in DPX Mountant for histology. The slides were assessed and documented with a BX50 microscope (Olympus) with NIS Elements AR 3.00 NIKON software.

For 5 metC localization the resin was removed with two changes of acetone and the slides were washed in distilled water and PBS pH 7.2. Before immunocytochemical reactions the sections were incubated with $0.1 \%$ RNAse for $30 \mathrm{~min}$ at $37^{\circ} \mathrm{C}$ and washed in PBS $\mathrm{pH} 7.2$ ( $3 \times 5 \mathrm{~min} ., 30 \mathrm{~min}$ at $\left.37^{\circ} \mathrm{C}\right)$. After neutralization of the medium with $0.1 \mathrm{M}$ $\mathrm{Na}_{2} \mathrm{~B}_{4} \mathrm{O}_{7} \times 10 \mathrm{H}_{2} \mathrm{O}$ (10 min at room temperature), the sections were incubated with anti-5metC mouse (Abcam) primary antibody (1:200 in 1\% BSA in PBS pH 7.2 for $12 \mathrm{~h}$ at $4^{\circ} \mathrm{C}$ ) and secondary goat anti-mouse antibody Alexa Fluor 488 (Invitrogen) diluted 1:1000 in $1 \% \mathrm{BSA}-1 \mathrm{~h}$ at $37^{\circ} \mathrm{C}$. DNA was stained with 4,6-diamidino-2-phenylindole (DAPI; Fluka). Finally, the sections were washed in PBS pH 7.2, dried at room temperature and covered with ProLongTMGold antifade reagent (Thermo Fisher Scientific). The control reactions omitted the incubation with primary antibodies. Semithin sections were analyzed with an Olympus BX50 fluorescence microscope, with a UPlanFI 1009 (N.A. 1.3) oil immersion lens and narrow band filters (U-MNU, U-MNG). The results were recorded with an Olympus XC50 digital color camera and CellB software (Olympus Soft Imaging Solutions $\mathrm{GmbH}$, Germany).

\section{Quantitative evaluation of 5-metC content}

The quantitative measurements of 5-metC levels were performed in the root apex cells. For this study, each experiment was carried out at the same temperature, incubation times, and antibody concentrations [72]. Image $(1.47 \mathrm{v})$ software was used for image processing and analysis. Before quantification of the fluorescence intensity, the background was eliminated by adjusting a threshold according to autofluorescence based on the negative control. The fluorescence intensity was measured for five semithin sections per experimental variant at the same magnification and constant exposure time to ensure comparable results. For each zone of the root apex 15 to 30 cells were analyzed depending on the experiment. The level of fluorescence was expressed in arbitrary units (as mean intensity per $\mu \mathrm{m}^{2}$ ). Figures were prepared in Microsoft Excel 2010.

\section{DNA extraction and Methylation-Sensitive Amplified Polymorphism (MSAP) procedure}

Tissues for the MSAP procedure were collected from three biological replicates. Each replicate consisted of leaves (second leaf) and the whole root system from three individual plants per treatment combination (control, Mn only, a combination of Mn and Se, and Se only). The leaves and roots were homogenized in liquid nitrogen and subjected to DNA extraction using micro-CTAB method [73]. Then, $250 \mu \mathrm{g}$ of DNA were used for restriction with two combinations of enzymes in $10 \mu \mathrm{l}$ of the reaction mixture: HpaII / EcoRI and MspI / EcoRI (New England Biolabs) in 1 x CutSmart Buffer with $1.25 \mathrm{U}$ of each of the restriction enzymes. The restriction reaction was run at $37^{\circ} \mathrm{C}$ for 3 hours with subsequent inactivation of the enzymes at $70^{\circ} \mathrm{C}$ for $10 \mathrm{~min}$. Two technical replications of both restriction combinations were used to cut each DNA sample. The restriction fragments were then subjected to 16 hours of adapter ligation at $37^{\circ} \mathrm{C}$, by adding $6 \mu \mathrm{l}$ of a mix containing 30 pmol of HpaII/MspI adapter, 3 pmol of EcoRI adapter (Table A1), 0.6 U of T4 DNA ligase (Thermo Fischer Scientific) and 1 x T4 DNA ligase buffer. Then, $1 \mathrm{ml}$ of DNA after ligation was used for preamplification reaction (10 $\mathrm{ml}$ of total volume) and mixed with 15 ng of HpaII/MspI+T and Eco+A primers (Table A1), $200 \mathrm{mM}$ of each dNTPs (Promega), 0.25 U Taq polymerase (DreamTaq, ThermoFischer Scientific) and $1 \times$ PCR buffer. The PCR conditions were as follows: 20 cycles of $30 \mathrm{sec}$ at $94^{\circ} \mathrm{C}, 40 \mathrm{sec}$ at $56^{\circ} \mathrm{C}$ and $50 \mathrm{sec}$ at $72^{\circ} \mathrm{C}$. The preamplified DNA was diluted 10 times and $2.5 \mu \mathrm{l}$ were taken as a template for the selective amplification. In this step, $0.5 \mathrm{pmol}$ of EcoRI selective primer labeled with a fluorescent dye IRD 800 (MWG), $12.5 \mathrm{ng}$ of MseI primer, $200 \mu \mathrm{M}$ of each dNTPs (Amersham Pharmacia), $0.3 \mathrm{U}$ of Taq polymerase (DreamTaq, ThermoFischer Scientific), $1 \mathrm{mM}$ $\mathrm{MgCl}_{2}$ and $1 \times$ PCR buffer supplemented with $2 \mathrm{mM} \mathrm{MgCl}_{2}$ were used in a total volume of $10 \mu \mathrm{l}$ reaction. The PCR was performed in the following conditions: 12 cycles of 
“touchdown" PCR of $30 \mathrm{sec}$ at $94^{\circ} \mathrm{C}, 30 \mathrm{sec}$ at $68^{\circ} \mathrm{C}$ (decreasing $0.7^{\circ} \mathrm{C}$ per cycle) and $1 \mathrm{~min}$ at 72 , followed by 23 cycles of $30 \mathrm{sec}$ at $94^{\circ} \mathrm{C}, 30 \mathrm{sec}$ at $59^{\circ} \mathrm{C}$, and $1 \mathrm{~min}$ at $72^{\circ} \mathrm{C}$. All together 11 selective primer combinations were used in the analysis (Table A2). After the PCR, $4 \mu 1$ of formamide gel loading buffer were added into the samples and, after denaturation at $95^{\circ} \mathrm{C}$ for $3 \mathrm{~min}, 0.8 \mathrm{\mu l}$ samples were loaded into polyacrylamide gels composed of $6 \%$ acrylamide/bis-acrylamide 19:1 solution (Sigma), $7 \mathrm{M}$ urea (Amersham Pharmacia), and 1 $x$ TBE buffer. Li-Cor DNA sequencer was used for the electrophoresis at the following parameters: $1400 \mathrm{~V}, 30 \mathrm{~mA}, 30 \mathrm{~W}$. Medium speed of a laser scanning was used.

\section{MSAP data analysis}

To describe the changes in DNA methylation all MSAP bands that met the following two conditions were analyzed: (i) the band pattern was replicable in two technical replications of each DNA sample and (ii) the same band pattern was present in all three biological replicates representing particular treatment combination. Several profiles in MSAP loci were possible: (i) monomorphic loci, characterized by the presence of a band in all samples and in both restriction enzymes combinations; (ii) polymorphic loci of type I, characterized by the presence of a band in one restriction enzyme combination and the lack of a band in the second combination, while this presence/absence of a band was identical for all DNA samples. These loci reflected particular methylation status of cytosines in CCGG sequence recognized by HpaII and MspI restriction enzymes, but were unrelated to any methylation changes triggered by the treatment; (iii) polymorphic loci of type II, characterized by differences in the band pattern between treatment combinations, reflecting methylation changes in CCGG sequence related to the growth conditions. Only the last category of MSAP loci was taken into consideration.

The analysis of methylation changes was based on differences in sensitivity to cytosine methylation in CCGG sequence displayed by HpaII and MspI isoschizomers. Briefly, both enzymes can cleave non-methylated CCGG sequence. HpaII can also cut this sequence when external cytosine is hemimethylated [74, 75], and MspI is capable of cleaving this site when one or two internal cytosines are methylated [75]. Such a profile does not allow for identification of the methylation status of each cytosine in CCGG sequence with a perfect precision. It allows, however, for quantification of the most probable changes in methylation using one of the existing models of MSAP data interpretation. In our analysis, we followed the model proposed by Bednarek et al. [76] which takes into consideration all possible methylation statuses of both external and internal cytosines in CCGG sequence that may underline the presence or the lack of MSAP band after HpaII and MspI digestion. Based on this model, the percentage of demethylation (later encoded as de-Met) and de novo methylation (de novo-Met) events that may occur after a particular treatment vs. the control conditions was calculated. Additionally, this model also allows for quantifying the probable share of demethylation and de novo methylation of cytosines at symmetric CHG and CG sites (later encoded as de-Met-CHG and de-Met-CG or de novo-MetCHG and de novo-Met-CG). A more detailed description of the data quantification method is provided in the Appendix A.

\section{Statistical Analysis}

The results of biological experiments were reported as an average of triplicate repetitions ( \pm SD) and analyzed statistically using one-way ANOVA, followed by post-hoc (Duncan test) comparisons with Statistica Software version 9.1 (SAS Institute Inc., Cary, NC, USA). The significance level was set at $\mathrm{p}<0.05$.

\section{Conclusions}

The presented research demonstrates that the root system of wheat seedlings is where most plant reactions to toxic doses of $\mathrm{Mn}$ take place. The responses were indicated as a considerable reduction of root weight and disturbances of their macroscopic and 
microscopic structure, especially within the apical parts. Se ions may have a protective effect on plants also under Mn stress. The mechanism of action of Se ions was not related to a direct blockage of Mn influx to the cells. Se-stimulated uptake of Ca ions seems to be an important step in this process, enabling regeneration of root tissues.

Microscopic observations indicated the potential ability of the meristem zone of roots to modify their differentiation pattern under Mn stress, more significantly in the case of strong damage to the meristematic and cap cells. These changes were related to a progressive increase in global DNA methylation from dividing meristematic cells to elongating cells of the axial vascular cylinder and cortex, what was indicated for the first time in our studies. Based on the DNA methylation profiles detected by MSAP, we hypothesize that different types of methylation sites may undergo different changes in the methylation pattern. We presume that asymmetric $\mathrm{CHH}$ sequences may come under preferential methylation in the presence of high doses of Mn, which is blocked or slowed down by Se addition, whereas other types of sequences, i.e., CGs and CHGs may undergo preferential demethylation both under Mn and Mn + Se treatment.

In summary, it may be assumed that Mn ions accumulate mainly in the cells of the "main" root apex. After exceeding its maximum concentration, the meristematic cells die (apoptosis), but new root buds differentiate rapidly and compensate for the loss of the dead cells. Thus, the plant can still take up Mn that is transported to the leaves. This may explain why in cv. Nimfa roots, where we observed the formation of new meristematic centers, the toxic processes were not as pronounced as in cv. Alibi, despite greater Mn uptake. Another explanation may be the possibility of Mn storage in degenerated fragments of roots. Such effects were not seen in cv. Alibi, which absorbed less Mn but transported it to the leaves.

Author Contributions: Conceptualization, A.S. and M.S.; methodology, software and validation, A.S., M.S., E. B-K, K.N., A.J. and A.T.; formal analysis and writing-original draft preparation A. S., M.S., E. B-K, A. J. and M.F.; visualization, M.S., E. B-K. and A.J, supervision, M.F. All authors have read and agreed to the published version of the manuscript.

Institutional Review Board Statement: Not applicable.

Informed Consent Statement: Not applicable.

Data Availability Statement: Not applicable.

Conflicts of Interest: The author declares no conflict of interest.

\section{Appendix A}

Table A1. The list of adapter and primer sequences used for the MSAP analysis. A letter " $\mathrm{H}$ " indicates a primer for HpaII or MspI restriction site, a letter " $\mathrm{E}$ " indicates a primer for EcoRI recognition site.

\begin{tabular}{|l|l|}
\hline \multicolumn{1}{|c|}{ Name of the oligo } & \multicolumn{1}{c|}{ Sequence 5'-3' $^{\prime}$} \\
\hline Adapters for ligation & \\
\hline HpaII / Msp I adapter - strand 1 & GACGATGAGTCTAGAA \\
\hline HpaII / MspI adapter - strand 2 & CGTTCTAGACTCATC \\
\hline EcoRI adapter - strand 1 & CTCGTAGACTGCGTACC \\
\hline EcoRI adapter - strand 2 & AATTGGTACGCAGTCTAC \\
\hline & \\
\hline Primers for preamplification & \\
\hline Hpa+T (Msp+T) primer & GATGAGTCTAGAACGGT \\
\hline Eco+A primer & GACTGCGTACCAATTCA \\
\hline
\end{tabular}




\begin{tabular}{|l|l|}
\hline & \\
\hline \multicolumn{2}{|l|}{ Primers for selective amplification } \\
\hline H-TAC & GATGAGTCTAGAACGGTAC \\
\hline H-TAG & GATGAGTCTAGAACGGTAG \\
\hline H-TCA & GATGAGTCTAGAACGGTCA \\
\hline H-TGA & GATGAGTCTAGAACGGTGA \\
\hline H-TGC & GATGAGTCTAGAACGGTGC \\
\hline E-ACG & GACTGCGTACCAATTCACG \\
\hline E-ACT & GACTGCGTACCAATTCACT \\
\hline E-AGA & GACTGCGTACCAATTCAGA \\
\hline E-ACA & GACTGCGTACCAATTCACA \\
\hline
\end{tabular}

Table A2. The list of selective primer combinations used in the MSAP analysis

\begin{tabular}{|c|cc|}
\hline No. & \multicolumn{3}{|c|}{ Primer combination } \\
\hline 1 & E-ACG / & H-TAC \\
\hline 2 & E-ACG / & H-TGC \\
\hline 3 & E-ACG / & H-TCA \\
\hline 4 & E-ACT / & H-TAC \\
\hline 5 & E-ACT / & H-TGC \\
\hline 6 & E-ACT / & H-TCA \\
\hline 7 & E-AGA / & H-TGA \\
\hline 8 & E-AGA / & H-TAG \\
\hline 9 & E-ACA / & H-TGA \\
\hline 10 & E-ACA / & H-TAG \\
\hline 11 & E-ACG / & H-TGA \\
\hline
\end{tabular}

\section{References}

1. Nita, M.; Grzybowski, A. The Role of the Reactive Oxygen Species and Oxidative Stress in the Pathomechanism of the AgeRelated Ocular Diseases and Other Pathologies of the Anterior and Posterior Eye Segments in Adults. Oxid. Med. Cell. Longev. 2016, 2016, 3164734.

2. Ayala, A.; Munoz, M.F.; Arguelles, S. Lipid peroxidation: production, metabolism, and signaling mechanisms of malondialdehyde and 4-hydroxy-2-nonenal. Oxid. Med. Cell. Longev. 2014, 2014, 360438.

3. Sharma, A.; Shankhdhar, D.; Shankhdhar, S.C. The role of calcium in plant signal transduction under macronutrient deficiency stress. In Plant Micronutrient Use Efficiency; Hossain, M.A., Kamiya, T., Burritt, D.J., Phan Tran, L.S., Fujiwara, T., Eds.; Academic Press: London, 2017; pp. 181-196.

4. Cakmak, I.; Yazici, A.M. Magnesium: a forgotten element in crop production. Better crops 2010, 94(2), $23-25$.

5. Wang, M.; Zheng, Q.; Shen, Q.; Guo, S. The critical role of potassium in plant stress response. Int. J. Mol. Sci. 2013, 1-4(4),73707390.

6. Liang, T.; Ding, H.; Wang, G.; Kang, J.; Pang, H.; Lv, J. Sulfur decreases cadmium translocation and enhances cadmium tolerance by promoting sulfur assimilation and glutathione metabolism in Brassica chinensis L. Ecotoxicol. Environ. Saf. 2016, 124, $129-137$.

7. Razaq, M.; Zhang, P.; Shen, H.L. Influence of nitrogen and phosphorous on the growth and root morphology of Acer mono. PloS one 2017, 12(2), e0171321. 
8. Malhotra, H.; Sharma, S.; Pandey, R. Phosphorus nutrition: Plant growth in response to deficiency and excess. In Plant Nutrients and Abiotic Stress Tolerance; Hasanuzzaman, M., Fujita, M., Oku, H., Nahar, K., Hawrylak-Nowak, B., Eds.; Springer: Singapore, 2018; pp. 171-190.

9. Sasaki, A.; Yamaji, N.; Yokosho, K.; Ma, J.F. Nramp5 is a major transporter responsible for manganese and cadmium uptake in rice. Plant Cell. 2012, 24, 2155-2167.

10. Andresen, E.; Peiter, E.; Küpper, H. Trace metal metabolism in plants. J. Exp. Bot. 2018, 69, 909-954.

11. Hafeez, B.; Khanif, Y. M.; Saleem, M. Role of zinc in plant nutrition-a review. J. Exp. Agric. Int. 2013, 3(2), $374-391$.

12. Rout, G.R.; Sahoo, S. Role of iron in plant growth and metabolism. J. Agric. Sci. 2011, 3,1-24.

13. Scheers N. Regulatory effects of $\mathrm{Cu}, \mathrm{Zn}$, and Ca on Fe absorption: the intricate play between nutrient transporters. Nutrients 2013, 5(3),957-970.

14. Broadley, M.; Brown, P.; Cakmak, I.; Rengel, Z.; Zhao, F. Function of nutrients: Micronutrients. In Mineral Nutrition of Higher Plants; Marschner, P., Ed.; Academic Press Inc.: San Diego, CA, USA, 2012; pp. 191-248.

15. Schmidt, S.B.; Husted, S. The biochemical properties of manganese in plants. Plants, 2019, 8(10), 381.

16. Maathuis, F.J.; Diatloff, E. Roles and functions of plant mineral nutrients. In Plant Mineral Nutrients; Springer: Berlin/Heidelberg, Germany, 2013; pp. 1-21.

17. Rahman, A.; Hossain, M.S.; Mahmud, J.A.; Nahar, K.; Hasanuzzaman, M.; Fujita, M. Manganese-induced salt stress tolerance in rice seedlings: regulation of ion homeostasis, antioxidant defense and glyoxalase systems. Physiol. Mol. Biol. Plants. 2016, 22(3), 291-306.

18. Sebastian, A.; Prasad, M.N.V. Iron- and manganese-assisted cadmium tolerance in Oryza sativa L.: Lowering of rhizotoxicity next to functional photosynthesis. Planta 2015, 241, 1519-1528. Sergiev, I.; Alexieva, V.; Karanov, E.; Effect of spermine, atrazine and combination between them on some endogenous protective systems and stress markers in plants. Compt. Rend. Acad. Bulg. Sci. 1997, 51(3), 121-124.

19. Gzyl-Malcher, B.; Rudolphi-Skórska, E.; Sieprawska, A.; Filek M. Manganese protects wheat from the mycotoxin zearalenone and its derivatives. Sci. Rep. 2019, 9(1), 1-12.

20. Li, Q.; Chen, L.-S.; Jiang, H.-X.; Tang, N.; Yang, L.-T.; Lin, Z.-H.; Li, Y.; Yang, G.-H. Effects of manganese-excess on CO 2 assimilation, ribulose-1,5-bisphosphate carboxylase/oxygenase, carbohydrates and photosynthetic electron transport of leaves, and antioxidant systems of leaves and roots in Citrus grandis seedlings. BMC Plant Biol. 2010, 10, 42.

21. Führs, H.; Kopka, J.; Braun, H.P.; Horst, W.J. Metabolomic and Proteomic Analysis of Manganese Sensitivity and Tolerance in the Tropical Legume Cowpea (Vigna unguiculata L.). The Proceedings of the International Plant Nutrition Colloquium XVI 2009, pp. 1068.

22. Führs, H.; Specht, A.; Erban, A.; Kopka, J.; Horst, W.J. Functional associations between the metabolome and manganese tolerance in Vigna unguiculata. J. Exp. Bot. 2012, 63(1), 329-340.

23. Fecht-Christoffers, M.M.; Braun, H.P.; Lemaitre-Guillier, C.; VanDorsselaer, A.; Horst, W.J. (2003) Effect of manganese toxicity on the proteome of the leaf apoplast in cowpea. Plant. Physiol. 2003, 133(4),1935-1946.

24. Sharma, S.S.; Dietz, K.J. The relationship between metal toxicity and cellular redox imbalance. Trends Plant Sci. 2009, 14(1), 4350.

25. Shi, Q.; Zhu, Z. Effects of exogenous salicylic acid on manganese toxicity, element contents and antioxidative system in cucumber. Environ. Exp. Bot. 2008, 63(1-3), 317-326.

26. Millaleo, R.; Reyes-Díaz, M.; Alberdi, M.; Ivanov, A.G.; Krol, M.; Hüner, N.P.A. (2013) Excess manganese differentially inhibits photosystem I versus II in Arabidopsis thaliana. J. Exp. Bot. 2013, 64(1), 343-354.

27. Chen, Z.; Yan, W.; Sun, L.; Tian, J.; Liao, H. Proteomic analysis reveals growth inhibition of soybean roots by manganese toxicity is associated with alteration of cell wall structure and lignification. J. Proteomics 2016, 143, 151-160.

28. Rajpoot, R.; Srivastava, R.K.; Rani, A.; Pandey, P.; Dubey, R.S. Manganese-induced oxidative stress, ultrastructural changes, and proteomics studies in rice plants. Protoplasma 2021, 258(2), 319-335.

29. Sieprawska, A.; Kornaś, A.; Filek, M. Involvement of selenium in protective mechanisms of plants under environmental stress conditions-review. Acta Biol. Crac. Ser. Bot. 2015, 57(1), 9-20.

30. Mechora, Š. Selenium as a protective agent against pests: a review. Plants 2019, 8(8), 262.

31. Gupta, M.; Gupta, S. An overview of selenium uptake, metabolism, and toxicity in plants. Front. Plant Sci. 2017, 7, 2074.

32. Koselski, M.; Dziubińska, H.; Trębacz, K.; Sieprawska, A.; Filek, M. The Role of SV Ion Channels Under the Stress of Mycotoxins Induced in Wheat Cells - Protective Action of Selenium Ions. J. Plant Growth Regul. 2019, 38(4), 1255-1259.

33. Sieprawska, A.; Filek, M.; Tobiasz, A.; Bednarska-Kozakiewicz, E.; Walas, S.; Dudek-Adamska, D.; Grygo-Szymanko, E. Response of chloroplasts of tolerant and sensitive wheat genotypes to manganese excess: Structural and biochemical properties. Acta Physiol. Plant. 2017, 39, 6.

34. Filek, M.; Keskinen, R.; Hartikainen, H.; Szarejko, I.; Janiak, A.; Miszalski, Z.; Golda, A. The protective role of selenium in rape seedlings subjected to cadmium stress. J. Plant Physiol. 2008, 165, 833-844.

35. Kleiber, T.; Krzesiński, W.; Przygocka-Cyna, K.; Spiżewski, T. Alleviation effect of selenium on manganese stress of plants. Ecol. Chem. Eng. 2018, 25(1),143-152.

36. Grafi, G.; Florentin, A.; Ransbotyn, V.; Morgenstern, Y. The stem cell state in plant development and in response to stress. Front. Plant Sci. 2011, 2, 53.

37. Chen, X.; Zhou, D.X. Rice epigenomics and epigenetics: challenges and opportunities. Curr. Opin. Plant Biol. 2013, 16(2), 164169. 
38. Guzy-Wrobelska, J.; Filek, M.; Kaliciak, A.; Szarejko, I.; Macháčková, I.; Krekule, J.; Barciszewska, M. Vernalization and photoperiod-related changes in the DNA methylation state in winter and spring rapeseed. Acta Physiol. Plant 2013, 35, 817-827.

39. Karan, R.; DeLeon, T.; Biradar, H.; Subudhi, P.K. Salt stress induced variation in DNA methylation pattern and its influence on gene expression in contrasting rice genotypes. PloS one, 2012, 7(6), e40203.

40. Greco, M.; Chiappetta, A.; Bruno, L.; Bitonti, M.B. In Posidonia oceanica cadmium induces changes in DNA methylation and chromatin patterning. J. Exp. Bot. 2012, 63(2), 695-709.

41. Tan, M.P. Analysis of DNA methylation of maize in response to osmotic and salt stress based on methylation-sensitive amplified polymorphism. Plant Physiol. Biochem. 2010, 48(1), 21-26.

42. Shan, X.; Wang, X.; Yang, G.; Wu, Y.; Su, S.; Li, S.; Liu, H.; Yuan, Y. Analysis of the DNA methylation of maize (Zea mays L.) in response to cold stress based on methylation-sensitive amplified polymorphisms. J. Plant Biol. 2013, 56, 32-38.

43. Gayacharan Joel, A.J. Epigenetic responses to drought stress in rice (Oryza sativa L.). Physiol. Mol. Biol. Plants. 2013, 19(3), 379387.

44. Huang, H.; Zhao, Y.; Xu, Z.; Zhang, W.; Jiang K. Physiological responses of Broussonetia papyrifera to manganese stress, a candidate plant for phytoremediation. Ecotoxicol. Environ. Saf. 2019, 181, 18-25.

45. Jaleel, C.A.; Manivannan, P.; Wahid, A.; Farooq, M.; Al-Juburi, H.J.; Somasundaram, R.; Panneerselvam, R. Drought stress in plants: A review on morphological characteristics and pigments composition. Int. J. Agric. Biol. 2009, 11, $100-105$.

46. Yao, Y.; Xu, G.; Mou, D.; Wang, J.; Ma, J. Subcellular Mn compartation, anatomic and biochemical changes of two grape varieties in response to excess manganese. Chemosphere, 2012, 89(2), 150-157.

47. Kim, Y.Y.; Choi, H.; Segami, S.; Cho, H.T.; Martinoia, E.; Maeshima, M.; Lee, Y. AtHMA1contributes to the detoxification of excess Zn(II) in Arabidopsis. Plant J. 2009, 58, 737-753.

48. Millaleo, R.; Reyes-Díaz, M.; Ivanov, A.G.; Mora, M.L.; Alberdi, M. Manganese as essential and toxic element for plants: Transport, accumulation and resistance mechanisms. J. Soil Sci. Plant Nutr. 2010, 10, 470-481.

49. Yang, M.; Zhang, Y.Y.; Zhang, L.; Hu, J.; Zhang, X.; Lu, K.; Dong, H.; Wang, D.; Zhao, F.J.; Huang, C.F.; et al. OsNRAMP5 contributes to manganese translocation and distribution in rice shoots. J. Exp. Bot. 2014, 65, 4849-4861.

50. Juice, S.M.; Fahey, T.J.; Siccama, T.G.; Driscoll, C.T.; Denny, E.G.; Eagar, C.; Cleavitt, N.L.; Minocha, R.; Richardson, A.D. Response of sugar maple to calcium addition to northern hardwood forest. Ecology 2006, 87, 1267-1280.

51. Kleiber, T. Effect of Manganese Nutrition on Content of Nutrient and Yield of Lettuce (Lactuca Sativa L.) in Hydroponic. Ecol. Chem. Eng. 2014, 21(3), 529-537.

52. Thor, K. Calcium - Nutrient and messenger. Front. Plant Sci. 2019, 10, 440.

53. Wilkins, K.A.; Matthus, E.; Swarbreck, S.M.; Davies, J.M. Calcium-mediated abiotic stress signaling in roots. Front. Plant Sci. 2016, 7, 1296.

54. White, P.J.; Bowen, H.C.; Demidchik, V.; Nichols, C.; Davies, J.M. Genes for calcium-permeable channels in the plasma membrane of plant root cells. BBA-Biomembranes. 2002, 1564(2), 299-309.

55. Hepler, P.K. Calcium: a central regulator of plant growth and development. Plant Cell, 2005, 17(8), $2142-2155$.

56. Lamport, D.T.; Varnai, P. Periplasmic arabinogalactan glycoproteins act as a calcium capacitor that regulates plant growth and development. New Phytol. 2013, 197, 58-64.

57. Demidchik, V.; Shabala, S.N.; Davies, J.M. Spatial variation in $\mathrm{H}_{2} \mathrm{O}_{2}$ response of Arabidopsis thaliana root epidermal Ca ${ }^{2+}$ flux and plasma membrane $\mathrm{Ca}^{2+}$ channels. Plant J. 2007, 49(3), 377-386.

58. Filek, M.; Kościelniak, J.; Łabanowska, M.; Bednarska, E.; Bidzińska, E. Selenium-induced protection of photosynthesis activity in rape (Brassica napus) seedlings subjected to cadmium stress. Fluorescence and EPR measurements. Photosynth. Res. 2010, 105, 27-37.

59. Rosa, M.; Prado, C.; Podazza, G.; Interdonato, R.; González, J.A.; Hilal, M.; Prado, F.E. Soluble sugars: Metabolism, sensing and abiotic stress: A complex network in the life of plants. Plant Signal. Behav. 2009, 4(5), 388-393.

60. Kumpf, R.P.; Nowack, M. K. The root cap: a short story of life and death. J. Exp. Bot. 2015, 66(19), 5651-5662.

61. Brown, P.T.H. DNA methylation in plants and its role in tissue culture. Genome, 1989, 31(2), 717-729.

62. Ikeuchi, M.; Iwase, A.; Sugimoto, K. Control of plant cell differentiation by histone modification and DNA methylation. Curr. Opin. Plant Biol. 2015, 28, 60-67.

63. Fan, X.; Hou, T.; Guan, Y.; Li, X.; Zhang, S.; Wang, Z. Genomic responses of DNA methylation and transcript profiles in zebrafish cells upon nutrient deprivation stress. Sci. Total Environ. 2020, 722, 137980.

64. Zhang, H.; Lang, Z.; Zhu, J.K. Dynamics and function of DNA methylation in plants. Nat. Rev. Mol. Cell. Biol. 2018, 19(8), 489506.

65. Tran, R.K.; Henikoff, J.G.; Zilberman, D.; Ditt, R.F.; Jacobsen, S.E.; Henikoff, S. DNA methylation profiling identifies CG methylation clusters in Arabidopsis genes. Curr Biol. 2005, 15(2), 154-9.

66. Bewick, A.J.; Schmitz, R.J. Gene body DNA methylation in plants. Curr. Opin. Plant Biol. 2017, 36, $103-110$.

67. Sergiev, I.; Alexieva, V.; Karanov, E. Effect of spermine, atrazine and combination between them on some endogenous protective systems and stress markers in plants. Compt. Rend. Acad. Bulg. Sci. 1997, 51, 121-124.

68. Janeczko, A.; Biesaga-Kościelniak, J.; Oklešt'ková, J.; Filek, M.; Dziurka, M.; Szarek-Łukaszewska, G.; Kościelniak, J. Role of 24epibrassinolide in wheat production: physiological effects and uptake. J. Agron. Crop. Sci. 2010, 196(4), 311-321.

69. Dhindsa, R.S.; Plumb-Dhindsa, P.; Thorpe, T.A. Leaf senescence: correlated with increased levels of membrane permeability and lipid peroxidation, and decreased levels of superoxide dismutase and catalase. J. Exp. Bot. 1981, 32(1), 93-101. 
70. Tobiasz, A.; Walas, S.; Filek, M.; Mrowiec, H.; Samsel, K.; Sieprawska, A.; Hartikainen, H. Evaluation of selenium effect on micro-and macroelements distribution to different wheat tissues during principal plant development stages. Biol. Plant. 2014, 58, 370-374.

71. Niedojadło, K.; Hyjek, M.; Bednarska-Kozakiewicz, E. Spatial and temporal localization of homogalacturonans in Hyacinthus orientalis L. ovule cells before and after fertilization. Plant Cell Rep. 2015, 34(1), 97-109.

72. Kozłowska, M.; Niedojadło, K.; Brzostek, M.; Bednarska-Kozakiewicz, E. Epigenetic marks in the Hyacinthus orientalis L. mature pollen grain and during in vitro pollen tube growth. Plant Reprod. 2016, 29(3), 251-263.

73. Doyle, J.J.; Doyle, J.L. A rapid DNA isolation procedure for small quantities of fresh leaf tissue. Phytochemical Bulletin, 1987, 19, 11-15.

74. Mann, M.B.; Smith, H.O. Specificity of HpaII and HaeIII DNA methylases. Nucleic Acids Res. 1977, 4(12), 4211-4221.

75. Reyna-Lopez, G.E.; Simpson, J.; Ruiz-Herrera, J. Differences in DNA methylation patterns are detectable during the dimorphic transition of fungi by amplification of restriction polymorphisms. Mol. Gen. Genet. 1997, 253(6), 703-710.

76. Bednarek, P.T.; Orłowska, R.; Niedziela, A. A relative quantitative methylation-sensitive amplified polymorphism (MSAP) method for the analysis of abiotic stress. BMC plant biology 2017, 17(1), 1-13.

In the text, reference numbers should be placed in square brackets [ ] and placed before the punctuation; for example [1], [1-3] or $[1,3]$. For embedded citations in the text with pagination, use both parentheses and brackets to indicate the reference number and page numbers; for example [5] (p. 10), or [6] (pp. 101-105). 